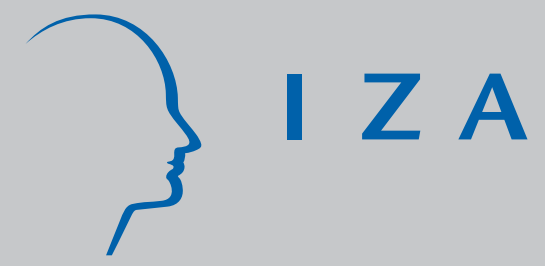

IZA DP No. 4267

Causes and Consequences of a Father's Child Leave:

Evidence from a Reform of Leave Schemes

Helena Skyt Nielsen

June 2009 


\title{
Causes and Consequences of a Father's Child Leave: Evidence from a Reform of Leave Schemes
}

\author{
Helena Skyt Nielsen \\ Aarhus University \\ and IZA \\ Discussion Paper No. 4267 \\ June 2009 \\ IZA \\ P.O. Box 7240 \\ 53072 Bonn \\ Germany \\ Phone: +49-228-3894-0 \\ Fax: +49-228-3894-180 \\ E-mail: iza@iza.org
}

\begin{abstract}
Any opinions expressed here are those of the author(s) and not those of IZA. Research published in this series may include views on policy, but the institute itself takes no institutional policy positions.

The Institute for the Study of Labor (IZA) in Bonn is a local and virtual international research center and a place of communication between science, politics and business. IZA is an independent nonprofit organization supported by Deutsche Post Foundation. The center is associated with the University of Bonn and offers a stimulating research environment through its international network, workshops and conferences, data service, project support, research visits and doctoral program. IZA engages in (i) original and internationally competitive research in all fields of labor economics, (ii) development of policy concepts, and (iii) dissemination of research results and concepts to the interested public.
\end{abstract}

IZA Discussion Papers often represent preliminary work and are circulated to encourage discussion. Citation of such a paper should account for its provisional character. A revised version may be available directly from the author. 


\section{ABSTRACT}

\section{Causes and Consequences of a Father's Child Leave: Evidence from a Reform of Leave Schemes}

Many OECD countries have implemented policies to induce couples to share parental leave. This paper investigates how responsive intra-household leave-sharing is to changes in economic incentives. To investigate this fundamental question, we are forced to look at one of the Nordic countries which are the most progressive when it comes to family-friendly policies. An extensive reform of child leave schemes in Denmark affected couples differently depending on whether the parents where employed in the same or in different parts of the public sector. Based on a difference-in-differences strategy, I find that economic incentives are very important for intra-household leave-sharing. Increasing the couples' after tax income by $\$ 9$ per day of leave which is transferred from the mother to the father is found to lead to a one day transfer. This corresponds to a supply elasticity close to unity.

JEL Classification: J13, J22, J45, J48

Keywords: fathers, parental leave, child leave

Corresponding author:

Helena Skyt Nielsen

School of Economics and Management

Aarhus University

Bartholins Allé 10

8000 Aarhus C

Denmark

E-mail: hnielsen@econ.au.dk

\footnotetext{
* I appreciate valuable comments from Marianne Simonsen and Mette Verner as well as those of seminar participants at Stockholm University, Stockholm School of Economics, Helsinki Center for Economic Research (HECER), NCoE Summer Institute in Bergen, Aarhus University and Danish Institute of Governmental Research (AKF). I am grateful to Søren Bundgaard Brøgger for competent research assistance. The usual disclaimer applies.
} 


\section{Introduction}

Policies to induce the fathers to use parental leave schemes have been introduced in many OECD countries (e.g. Austria, Portugal, Germany, Denmark, Finland, Sweden, Norway and Iceland). However, not much is known about the causes and consequences of increased leave-sharing. This paper contributes to filling this gap in the literature by investigating the causal impact of economic incentives on publicly employed fathers' use of parental leave as well as the consequences of leave-sharing on the subsequent labor market career of the father and the mother. This is possible due to an extensive reform of the Danish child leave schemes in 2002 which affected publicly employed couples differently depending on whether they where employed in the same or in different parts of the public sector (local vs. state).

As regards fathers' leave taking before this reform, Denmark was similar to e.g. the US; while $60 \%$ of Danish fathers used their right to take paid child leave in 2000 (average duration 3.5 weeks), $89 \%$ of US fathers took time off in relation to the births of their children (average duration 1.5. weeks) ${ }^{1}$. In comparison, $82 \%$ of Swedish fathers used their right to take paid parental leave around that time (average 8 weeks) ${ }^{2}$.

The economics literature on issues related to fathers' leave taking is scarce, and it is primarily based on Swedish and US data. This research is concerned with the effect of individual eligibility on leave taking as well as with the consequences on fathers and their children of their leave taking.

Increased individual eligibility to paid and unpaid parental leave schemes has caused fathers to increase their usage of the leave schemes. This result has been found both for the relatively moderate US parental leave schemes (Han, Ruhm and Waldfogel, 2009), where increased eligibility makes fathers increase leave taking by $50-80 \%$, and for the more generous Swedish parental leave schemes (Ekberg, Eriksson and Friebel, 2005; Eriksson, 2005), where a one-month quota dedicated to the father, makes fathers increase leave by 2 weeks on average. The US study bases identification on interstate variation over time and the Swedish studies base identification on a regression discontinuity design. Therefore, it is fair to interpret these studies as firm evidence that increased eligibility increases leave taking. However, it is still unclear which role economic incentives play for the fathers' decisions.

Regarding the analyses of the effects of child leave on the careers of fathers, Albrecht et al. (1999) and Stafford and Sundström (1996) find that the effect of child leave on wages is more detrimental for a father's career than it is for that of a mother. The relationship is identified by panel data methods, and the results have been interpreted as indicative that leave-taking signals a low level of career mindedness among fathers. A similar conclusion is reached by Bygren and Duvander (2006) who find that fathers tend to take a shorter leave if their work place is such that high career-related costs may be expected. Examples of such workplaces are found in the private sector, in small firms with few female employees and few other male employees using the leave schemes. Sociological studies confirm these conclusions (e.g. Lammi-Taskula, 2007; Hyde, Essex and Horton, 1993). When it comes to the analyses of the effects of the fathers' child leave on the careers of the mothers, Ekberg, Eriksson and

\footnotetext{
${ }^{1}$ The US figures relate to births in 2001, see Nepomnyaschy and Waldfogel (2007), while the Danish figures relate to births in 2000, see Statistics Denmark (2000) and Figure A1 in this paper.

${ }^{2}$ The Swedish figures relate to the period after the first daddy month reform in 1995, see Ekberg, Eriksson and Friebel (2005).
} 
Friebel (2005) and Pylkkänen and Smith (2003) find that the "Daddy month reform" in Sweden in 1995 meant that mothers returned faster to work after child birth, but this was due to the fact that the total amount of child leave available was held constant. Eriksson (2005) finds that the second "Daddy month reform" in 2002, which coincided with an increase in the total length of leave from 12 to 13 months, increased both the leave taking of the mother and the father. While the mentioned studies tend to find negative effects on the father's own career from leave taking, the mentioned studies provide no evidence of positive effects on his partner's career from his leave taking.

Considering the effects of child leave on male care-taking activities, Nepomnyaschy and Waldfogel (2007) find evidence that US fathers who take parental leave are more involved in dressing, feeding, bathing and getting up at night nine months after birth. The results may to some extent reflect selection effects rather than causal effects as identification relies on selection on observables. Looking at long run effects on male care-taking activities, Ekberg, Eriksson and Friebel (2005) find no effect of Swedish father's leave usage on their involvement in child care and household work when the child is eight years old. The authors argue that the results are likely to reflect causal effects as identification is based on comparison of fathers with children born slightly before and slightly after the introduction of the "daddy month", which increased father's leave by two weeks on average. It is perhaps not surprising that such a small increase in fathers' involvement has no long run effects. ${ }^{3}$

In this study, I exploit a reform of the paid leave regulation in Denmark in 2002. This reform affected couples differently depending on whether they were employed in the same or in different parts of the public sector. The public sector consists of two sub-sectors: a local sub-sector which comprises municipalities and counties (e.g. public child care, compulsory education, health services) and a state sub-sector (e.g. higher education, central administration). After the reform, all publicly employed fathers with partners employed in parts of the public sector different from their own suddenly got a strong economic incentive to take a part of the child-leave. No such change affected couples where the partners were employed in the same part of the public sector. The extent of the increased economic incentive depended on their wage. Based on a differences-in-differences strategy, I nail down the causal effect of economic incentives by estimating how price sensitive the leave-sharing decision is. Increasing the couples' after tax income by $\$ 9$ per day of leave which is transferred from the mother to the father is found to increase fathers' leave usage by one day. This corresponds to an elasticity of almost unity. However, the effect tends to increase as time passes by, and two years after its introduction, the same amount would increase fathers' leave usage one and a half day. As also indicated by Olsen (2007), individuals, local municipalities and employers found that the new leave scheme was quite complex, and this is most likely the main reason for the increase over time.

Furthermore, I investigate the effect of the increased intra-household leave sharing on the mother's and the father's subsequent careers. An increase in leave-sharing is associated with better career outcomes for the mother, and worsened career outcomes for the father. However, the mean response to the reform is only 2.6 days which is a small number in a career perspective, and it is not evident from the analysis that the estimated career effects represent significant causal effects.

The paper is organized as follows: Section 2 describes the child leave regulations in the public sector in Denmark during the relevant time period, and explains how the reform of 2002 may be used for

\footnotetext{
${ }^{3}$ Rasmussen (forthcoming) finds that a 10 weeks increase in maternity leave had no effect on long-run child outcomes.
} 
identification. Section 3 presents the data. Section 4 presents the empirical analysis. Section 5 concludes the paper.

\section{The public sector leave schemes and the reform}

Universal leave schemes have existed in Denmark since 1967, and they have been gradually improved in terms of duration and generosity of pay since then. As of today, a parent is individually eligible for one year of unpaid leave after child birth, while the couple is jointly eligible for one year of paid leave. For births in 2005, a mother used on average 254 days of paid leave (after birth) while a father used on average 30 days of paid leave. From 1994 to 2005, the father's share of the couple's total leave usage has almost constantly been $10 \%$. See figures A1 and A2 in the appendix.

In this section, the focus is on leave schemes and reforms influencing employees in the public sector which in 2005 employed $36 \%$ of the total number of employees (53\% of the employed women, $22 \%$ of the employed men). ${ }^{4}$ The public sector is at the forefront of defining favorable leave schemes, although the same schemes prevail in large parts of the private sector too. ${ }^{5}$

In the first sub-section below, the child leave schemes of the Danish public sector are described. After that, the changed interpretation of these schemes due to the flexible child leave reform of 2002 is presented. In the final sub-section, the use of this reform for identification is discussed.

\subsection{Child leave in the Danish public sector}

Since 1985, mothers have had the right to 4 weeks of pregnancy leave before the due date and 14 weeks of maternity leave after it, whereas fathers have been eligible for 2 weeks of paternity leave after birth. On the top of that, a parental leave of 10 weeks to be shared between the parents has existed. During periods of leave, the minimum compensation was defined by the maximum rate of unemployment insurance benefits (UI-benefits). Employers of working women who offered a higher compensation, received a reimbursement by the local authorities corresponding to the UI-benefits. ${ }^{6}$ From 1989, the collective agreements for the public sector implied full uncapped wage compensation during child leave. However, no more than a total of 10 weeks of paid parental leave were available for the parents to share regardless of whether one or both of the parents were publicly employed as the wage compensation is conditional on reimbursement from the local authorities. ${ }^{7}$

A number of reforms changed the leave schemes further. To alleviate problems with high unemployment, which peaked at $12.3 \%$ in 1993, an additional child care leave scheme was introduced so as to withdraw workers from the workforce. It allowed for an additional 52 weeks of paid child care

\footnotetext{
${ }^{4}$ See Statistics Denmark (2006)

${ }^{5}$ In the sector of finance, insurance and banking, leave schemes generally copy the public sector, while the national phone company (TDC) and the big pharmaceutical companies (such as Novo Nordisk), offer as good or better leave schemes than the public sector.

${ }^{6}$ It is only the level of pay that is related to the UI-benefits, eligibility for child leave does not require membership of a UIfund.

7 One exception is the pregnancy leave, where the local municipalities and local counties assure full uncapped wage compensation starting 8 weeks before the due date, while the state guarantees full uncapped wage compensation starting 6 weeks before the due date, even though the local authorities only reimburse an amount corresponding to UI-benefits 4 weeks before the due date.
} 
leave at a reduced compensation rate (to distinguish this from the other child leave schemes, this scheme is denoted: "the child care leave scheme"). ${ }^{8}$ In 1999 , two additional weeks of paternity leave were introduced to be taken at the end of (typically) the mothers' parental leave period, that is, in the $25^{\text {th }}$ and $26^{\text {th }}$ week after giving birth. In the public sector, this extra leave period prompted full wage compensation. In 2002, a flexible child leave reform abolished child care leave while extending the regular leave period with a relatively high compensation rate to a total of 52 weeks. Details about this reform follow in the next sub-section.

\subsection{The flexible child leave reform of 2002}

In January 2002, the draft legislation for a flexible child leave reform was presented. It was implemented for children born on March 27, 2002, and onwards. Parents of children born January 1, 2002 - March 26, 2002, could choose to use the old or new child leave scheme depending on their preferences.

The major changes introduced by this reform were the possibilities of simultaneous leave, part-time leave as well as a postponed leave period. However, the reform also extended the period with full benefit compensation from $4+14+10$ weeks to $4+14+32$ weeks, meaning that the parental leave to be shared between the two parents was extended from 10 to 32 weeks. This extension replaced the 52 weeks of child care leave (at a low compensation rate) as well as the two additional weeks of paternity leave to be taken by the father in weeks 25 and 26 after the birth. ${ }^{9}$

As a consequence of the flexible child leave reform, parents employed in the two different sub-sectors of the public sector suddenly got the opportunity of taking 10 weeks of parental leave each with a full uncapped wage compensation. The same opportunity was not available for parents employed in the same sub-sector. These parents still had to share the 10 week period with full uncapped wage compensation between them. Thus, the attractiveness of leave-sharing and the attractiveness of leavetaking for fathers, who would most often be the marginal users of child leave, improved substantially. It is unclear whether this change in incentives was intentional or not, but this does not matter for the present purpose.

Figure 1 illustrates the regime before and after the flexible child leave reform for couples employed in the public sector. Before the reform (top panel), the mother would get $4+14+10$ weeks of leave with full wage compensation, while the father would only get the 10 weeks of parental leave with full wage compensation, if the mother was willing to forego this part of the leave period. In addition to this child leave period, either parent could obtain child care leave for 52 weeks at a reduced rate $(60 \%$ of benefit level). After the reform, the situation was basically unchanged if the partners were employed in the same part of the public sector (mid panel), except, child care leave at a low compensation rate was replaced by an extension of the ordinary child leave scheme at a compensation rate determined by the maximum rate of UI-benefits. However, if the parents were employed in different parts of the public sector (bottom panel), the attractiveness of the father's use of the parental leave scheme was improved

\footnotetext{
${ }^{8}$ Until 1996, the compensation rate was $80 \%$ of the maximum rate of UI benefits. From 1.1.1996 the compensation rate was reduced to $70 \%$, while it was further reduced to $60 \%$ of the maximum rate of UI benefits on 1.4 .1997 , where it stayed until the scheme ended in 2002.

${ }^{9}$ In this respect the change is similar to the change in Germany studied by Bergemann and Riphahn (2009). The reform in Germany also reduced the length of leave while increasing the compensation rate.
} 
significantly, because he would now receive full uncapped wage compensation for an additional 10 weeks if the mother were willing to forego this part of the leave period. If she takes it herself, she would only get compensated by the rate of UI-benefit. This additional compensation is illustrated by gray area at the bottom panel of Figure 1. The economic incentive to let the father take the leave is indicated by the size of this gray area. In the sketch in Figure 1, W is twice as large as B, which is roughly correct for the average father in the sample to be used in this paper. However, generally speaking the size of the grey area varies, and the size indicates the absolute incentive to let the father take part of the parental leave.

\subsection{Using the reform for identification}

It is inherently difficult to identify the causal effect of economic incentives on leave-taking as the variation in economic incentives across individuals most often stems from time changes, interstate variation or variation in the sector, education or occupation of the individual. As a consequence the effect of economic incentives on leave-taking behavior would either be indistinguishable from endogenous policy responses or from systematic variation in preferences over time, across states and over sector, occupation or education.

However, the flexible child leave reform is almost ideal to identify the causal effect of economic incentives on the fathers' usage of child leave as it allows for an identification strategy which does not suffer from these drawbacks. In contrast to, for instance, the Swedish "Daddy month" reforms, it was not implemented with the particular purpose of influencing the leave decisions of fathers. Thus, the reform is unlikely to represent an endogenous policy response. The effect of the economic incentives on a sub-population of fathers can be regarded as an unintended byproduct of the reform affecting couples employed in different sectors and not as a result of the changed legislation as such.

Another important advantage of the policy is that the effect of the reform on economic incentives for fathers to take leave varied across otherwise identical individuals. The reform gave fathers in couples employed in different parts of the public sector incentives to take more of the parental leave than otherwise similar fathers in couples employed in the same sub-sector. Therefore, it gives me a natural treatment and control group. This interpretation assumes - quite uncontroversially - that the father is the marginal leave user, whose leave decision is affected by the improved economic incentives. ${ }^{10}$ Thus, we can employ a difference-in-differences approach, where couples in different sub-sectors (Different) are treated by improved economic incentives to let the father take part of the parental leave, while couples employed in the same sub-sectors are a control group.

The main identifying assumption is the standard difference-in-differences assumption that the treatment group and the control group are affected similarly by common trends in leave-taking behavior. In this particular context, the assumption is that other time-varying influences, such as the father's preference for leave-taking, business cycle effects, child care opportunities etc. should evolve identically over time for the two groups. This assumption also implies that the selection of couples into treatment is unrelated to the change introduced by the reform. This means that the decisions of the couples of whether or not to be employed in two different parts of the public sector (local and state) are unrelated to the extraordinarily generous leave conditions that the fathers would be eligible for if they were

\footnotetext{
${ }^{10}$ This corresponds to Olsen (2007), which reports that $94 \%$ of all mothers use 10 weeks of parental leave, while only $25 \%$ of the fathers take part of the parental leave after the reform.
} 
covered by different agreements. The identifying assumption is discussed in detail in the empirical analysis.

As it is evident from the above description of the reform, one potential problem with using this reform for identification is that the new scheme is relatively complicated. In fact, Olsen (2007) reports that parents, employers and local municipalities who administer the new law found the new scheme complicated to understand, and the author recommends publication of easy-to-read information material about the new leave scheme. This complicates identification because the couples in the treatment group may not even be aware of their treatment, and the effects may materialize gradually as information about the details of the new scheme is spread. For this reason, the estimated treatment effect is the "effect of the intention to treat".

\section{Data}

For the empirical analysis, a register-based dataset covering the Danish population 1980-2006 is used. The dataset contains socio-demographic information, such as age, gender, education, income, residence, and it is augmented by complete information about fertility and child leave histories. As a starting point, all births in the window 1997-2005 are selected, and then the sample is restricted to couples for whom data is available in the registers. Further selection criteria are described in detail below and summarized in Table 1.

In order to have exact information on the leave conditions of both parents, and in order to achieve identification, I select a sample of couples where the parties are publicly employed. First of all, the identification strategy is only relevant for couples where the male is eligible for full wage compensation if he uses all or part of the 10 weeks of parental leave. And, this is the case for all publicly employed fathers. Secondly, the main identifying assumption is that the treatment and the control group are influenced by a common trend in leave-taking behavior. The main concern is that the fathers' preferences for leave-taking are likely to increase over time, and the common trend assumption implies that this rise is assumed similar in the treatment and the control group. This concern means that it is an advantage to choose a relatively homogenous sample where the treated couples are relatively similar to the control group. For this reason, only couples where both parties completed a short-cycle, a medium-cycle or a long-cycle higher education are selected. However, the fact that they are educated also increases the likelihood that the couples understand the complicated flexible leave scheme, and thus that they are aware of whether they are treated or not. As a consequence, the main results of the empirical analysis should be interpreted conditional on being part of a well-educated, publicly employed couple. However, results for all publicly employed couples are presented as well as a robustness check.

Finally, I disregard couples whose children were born in the period January 1-March 26, 2002, where the opportunity was offered for them to choose which leave scheme to be covered by. I also leave out couples where none of the partners are recorded to take child leave as this is unlikely to be true. The sample selection process leaves me with 17,680 couples and births. 
Figure 1. Illustration of the child leave schemes before and after the reform (for parents with full wage compensation)

Before the reform
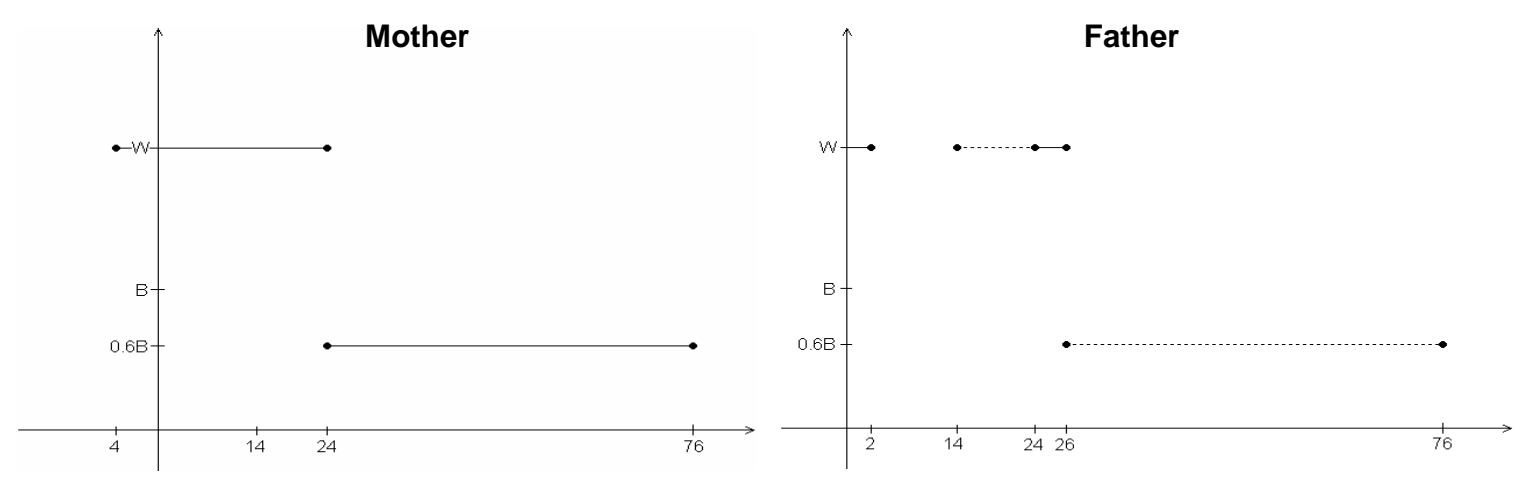

After the reform - same sub-sector
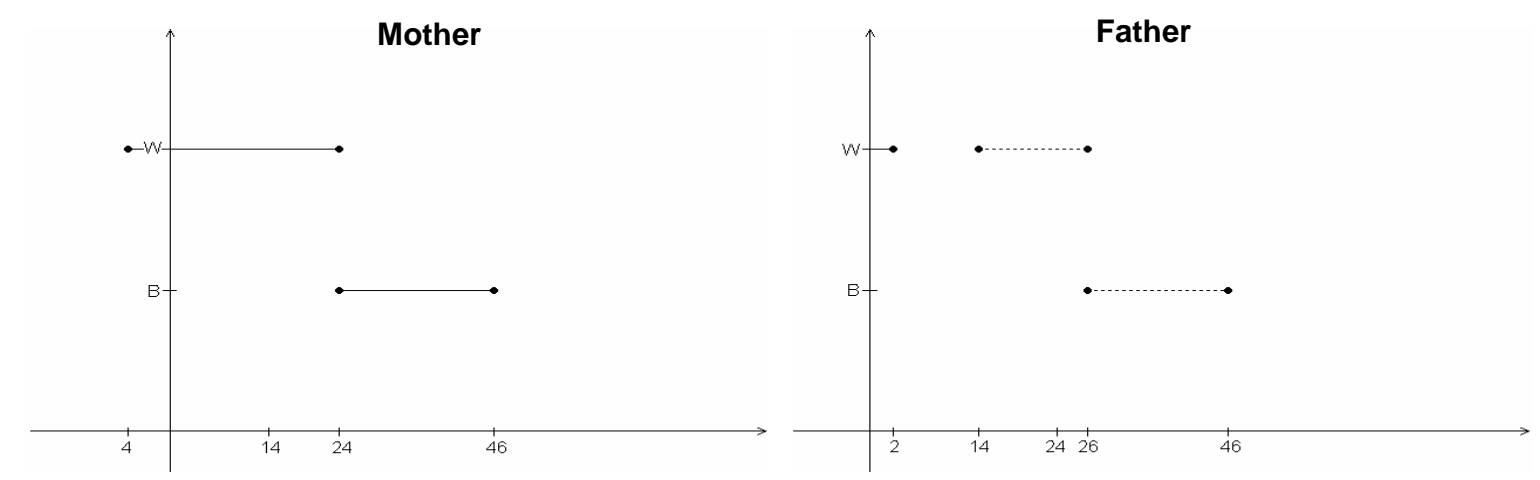

After the reform - different sub-sectors
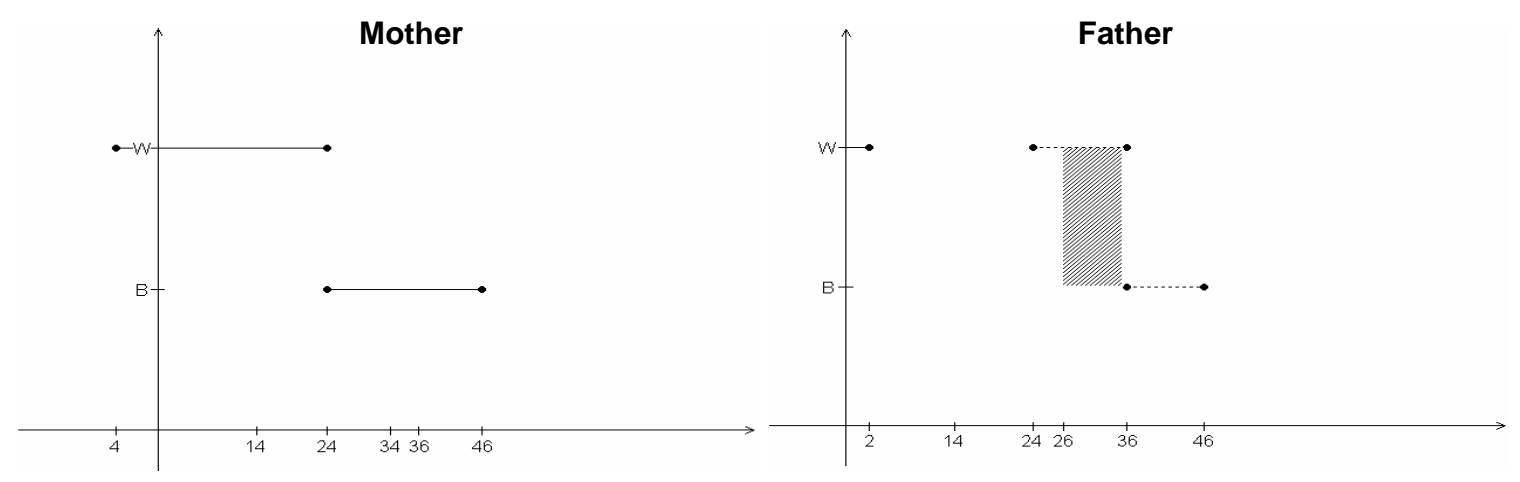

$\underline{\text { Legend }}$

compensation

potential compensation to the father if the mother foregoes leave 


\section{Table 1. Overview of the sample selection process}

\begin{tabular}{lr}
\hline Original samples sizes & \\
All births 1997-2005 (twins count only once) & 604,128 \\
Mother and father can be identified & 582,777 \\
Mother and father can be identified and data is available & 566,876 \\
Mother and father form a couple at birth & 536,967 \\
$\quad$ of which & \\
$\quad$ mother and father are aged 20 to 50 years & 531,361 \\
$\quad$ mother and father have completed higher education & 103,947 \\
$\quad$ mother and father are employed in the public sector & 34,948 \\
Final sample sizes & \\
All couples aged 20-50 years who are employed in the public sector & 33,889 \\
$\quad$ without births 1.1.02-26.3.02 and births without leave & $\mathbf{3 2 , 7 7 0}$ \\
All high educated couples aged 20-50 years who are employed in the public sector & 18,171 \\
$\quad$ without births 1.1.02-26.3.02 and births without leave & $\mathbf{1 7 , 6 8 0}$ \\
\hline
\end{tabular}

For each individual, the total number of leave days is computed. Figure 2 illustrates the distribution of leave days taken by the mother and the father before and after the reform in 2002. ${ }^{11}$ Among the fathers, $19 \%$ and $15 \%$ take no leave at all before and after the reform, respectively. Only few fathers use more than four weeks of child leave, but this fraction has increased from 13 to $22 \%$. For mothers, the main peak is at 23-24 weeks before the reform which corresponds to the period of full wage compensation, whereas after the reform there is also a peak at 45-46 weeks, which is the maximum period of paid leave. After the reform, many mothers take a longer leave than the period of full wage compensation; the fraction of mothers using more than 24 weeks increased from $54 \%$ to $83 \%$.

After the reform, $6.6 \%$ of the mothers are recorded to take more leave than what is allowed according to the schemes illustrated in Figure 1. In the empirical analysis, they are assumed to take no more than 46 weeks of leave, which is the maximum period of leave that they are allowed. Part of the reason is that some mothers have another child shortly after the child leave in question, which complicates the process of attributing leave to the right births. This is partly due to the fact that some mothers carry over pre-reform child care leave from earlier births.

\footnotetext{
${ }^{11}$ We disregard the pregnancy leave taken by the mother before the birth. If the couple uses the post-reform flexibility to go on part-time leave or extend the maximum leave period while reducing compensation, we compute the number of leave days as the corresponding number of full-time leave days.
} 


\section{Figure 2. Number of leave days taken before and after the reform}
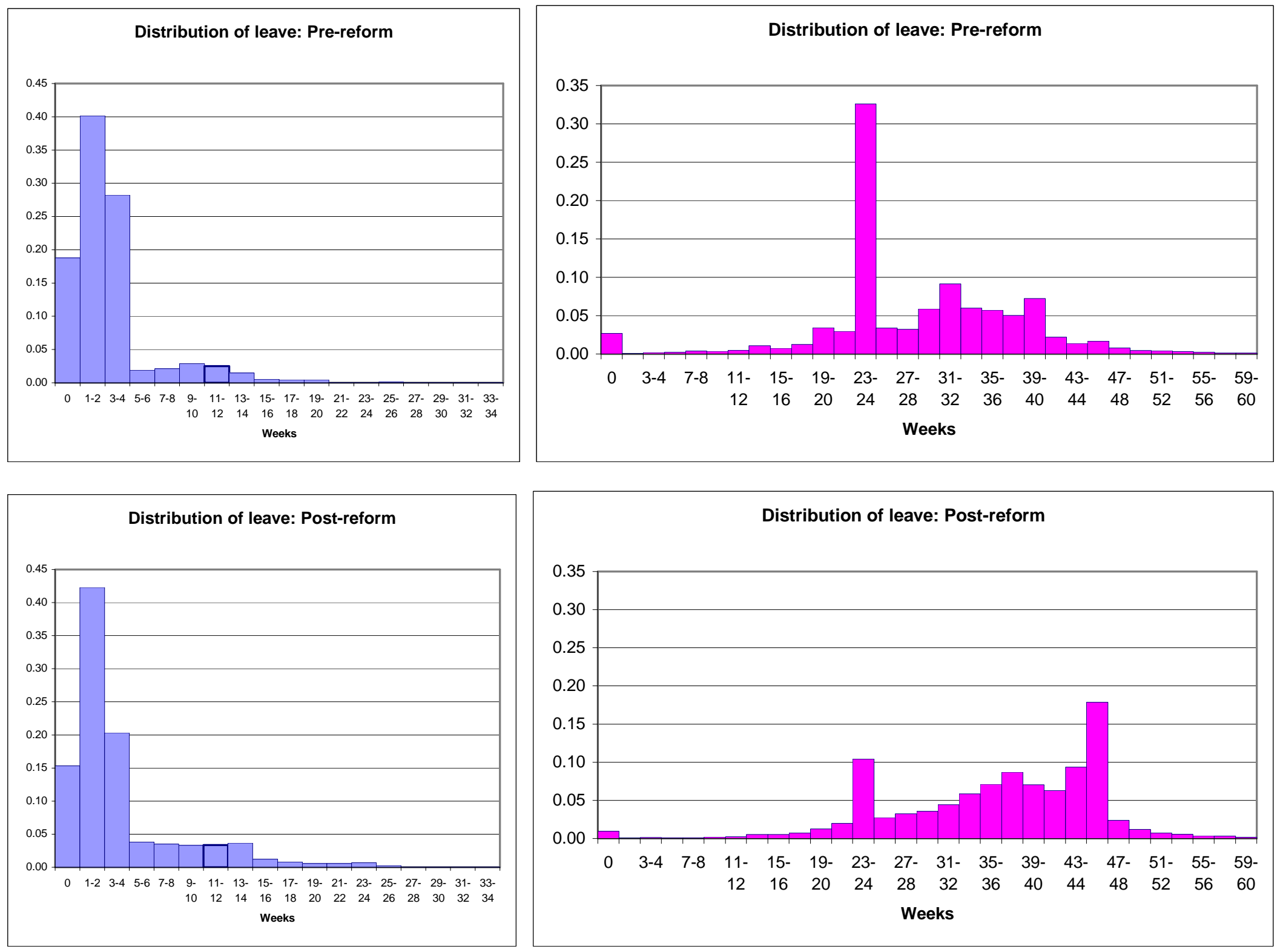


\section{Table 2. Data description}

\begin{tabular}{|c|c|c|c|c|c|c|c|c|}
\hline & \multicolumn{4}{|c|}{ Father } & \multicolumn{4}{|c|}{ Mother } \\
\hline & \multicolumn{2}{|c|}{ Same sub-sector } & \multicolumn{2}{|c|}{ Different sub-sector } & \multicolumn{2}{|c|}{ Same sub-sector } & \multicolumn{2}{|c|}{ Different sub-sector } \\
\hline & Mean & Std.dev. & Mean & Std.dev. & Mean & Std.dev. & Mean & Std.dev. \\
\hline \multicolumn{9}{|l|}{ Background characteristics } \\
\hline First child $(0 / 1)$ & 0.47 & - & 0.45 & - & 0.47 & - & 0.45 & - \\
\hline Second child $(0 / 1)$ & 0.42 & - & 0.44 & - & 0.42 & - & 0.44 & - \\
\hline Twin birth $(0 / 1)$ & 0.02 & - & 0.02 & - & 0.02 & - & 0.02 & - \\
\hline Big City (0/1) & 0.46 & - & 0.52 & - & 0.46 & - & 0.52 & - \\
\hline City $(0 / 1)$ & 0.30 & - & 0.28 & - & 0.30 & - & 0.28 & - \\
\hline Age & 34.6 & 5.1 & 34.4 & 4.7 & 32.3 & 3.7 & 32.5 & 3.7 \\
\hline Local $(0 / 1)$ & 0.81 & - & 0.21 & - & 0.81 & - & 0.79 & - \\
\hline Post reform $(0 / 1)$ & 0.54 & - & 0.52 & - & 0.54 & - & 0.52 & - \\
\hline \multicolumn{9}{|l|}{ Income variables } \\
\hline Labor income (DKK, 2006 prices) & 332738 & 129439 & 340628 & 126685 & 262873 & 90695 & 257144 & 95752 \\
\hline Labor income in year 2006 (DKK) & 387311 & 173126 & 410090 & 157883 & 296155 & 122796 & 293894 & 130504 \\
\hline Log (labor income, 2006 prices) & 12.6 & 0.5 & 12.6 & 0.5 & 12.4 & 0.5 & 12.3 & 0.6 \\
\hline Log (labor income in year 2006) & 12.6 & 1.7 & 12.7 & 1.5 & 12.2 & 1.9 & 12.1 & 2.1 \\
\hline Labor income-Benefit per day & - & - & 469.38 & 346.79 & - & - & 240.66 & 262.46 \\
\hline \multicolumn{9}{|l|}{ Career variables } \\
\hline Promotion, year 1 after birth $(0 / 1)$ & 0.11 & - & 0.13 & - & 0.07 & - & 0.09 & - \\
\hline Promotion, year 2 after birth $(0 / 1)$ & 0.13 & - & 0.15 & - & 0.09 & - & 0.11 & - \\
\hline Wage increase DKK, year 1 after birth & 41524 & 98055 & 44588 & 101423 & -26148 & 92234 & -27734 & 97836 \\
\hline Wage increase DKK, year 2 after birth & 61058 & 110011 & 63098 & 112415 & 31648 & 92675 & 30959 & 100609 \\
\hline Wage increase in pct, year 1 after birth & 0.19 & 0.86 & 0.20 & 0.97 & -0.09 & 0.91 & -0.09 & 1.12 \\
\hline Wage increase in pct, year 2 after birth & 0.29 & 1.15 & 0.34 & 1.33 & 0.27 & 1.51 & 0.26 & 1.45 \\
\hline \multicolumn{9}{|l|}{ Leave variables } \\
\hline No leave $(0 / 1)$ & 0.15 & - & 0.22 & - & 0.01 & - & 0.02 & - \\
\hline No parental leave $(0 / 1)$ & 0.80 & - & 0.82 & - & 0.03 & - & 0.03 & - \\
\hline Total leave (days) & 26.9 & 30.3 & 24.0 & 29.3 & 226.1 & 69.0 & 225.1 & 70.6 \\
\hline Parental leave (days) & 9.89 & 25.7 & 8.65 & 23.9 & 129.80 & 64.7 & 129.2 & 65.3 \\
\hline Share of total leave (\%) & 0.11 & 0.14 & 0.11 & 0.15 & 0.89 & 0.14 & 0.89 & 0.15 \\
\hline \multicolumn{9}{|l|}{ Education variables } \\
\hline $\operatorname{SCHE}(0 / 1)$ & 0.07 & - & 0.18 & - & 0.04 & - & 0.03 & - \\
\hline 1: SCHE SocSci $(0 / 1)$ & 0.01 & - & 0.02 & - & 0.01 & - & 0.01 & - \\
\hline 2: SCHE NatTech $(0 / 1)$ & 0.02 & - & 0.04 & - & 0.01 & - & 0.02 & - \\
\hline 3: SCHE PoliceArmy $(0 / 1)$ & 0.04 & - & 0.12 & - & 0.02 & - & 0.00 & - \\
\hline MCHE $(0 / 1)$ & 0.55 & - & 0.24 & - & 0.67 & - & 0.59 & - \\
\hline 4: MCHE PedTeach (0/1) & 0.42 & - & 0.10 & - & 0.42 & - & 0.27 & - \\
\hline 5: MCHE SocSci (0/1) & 0.03 & - & 0.03 & - & 0.03 & - & 0.04 & - \\
\hline 6: MCHE NatTech $(0 / 1)$ & 0.04 & - & 0.10 & - & 0.01 & - & 0.02 & - \\
\hline 7: MCHE Health (0/1) & 0.06 & - & 0.01 & - & 0.21 & - & 0.26 & - \\
\hline LCHE $(0 / 1)$ & 0.38 & - & 0.59 & - & 0.28 & - & 0.38 & - \\
\hline 8: LCHE Health (0/1) & 0.11 & - & 0.06 & - & 0.07 & - & 0.09 & - \\
\hline 9: LCHE SocSci (0/1) & 0.11 & - & 0.20 & - & 0.09 & - & 0.12 & - \\
\hline 10: LCHE NatTech $(0 / 1)$ & 0.10 & - & 0.22 & - & 0.06 & - & 0.07 & - \\
\hline 11: LCHE HumSci $(0 / 1)$ & 0.06 & - & 0.10 & - & 0.06 & - & 0.11 & - \\
\hline \multicolumn{9}{|l|}{ Occupation } \\
\hline 1: Manager $(0 / 1)$ & 0.02 & - & 0.02 & - & 0.01 & - & 0.00 & - \\
\hline 2: High-level salaried $(0 / 1)$ & 0.65 & - & 0.67 & - & 0.52 & - & 0.53 & - \\
\hline 3: Low-level salaried $(0 / 1)$ & 0.25 & - & 0.12 & - & 0.41 & - & 0.41 & - \\
\hline 4: Skilled $(0 / 1)$ & 0.06 & - & 0.16 & - & 0.05 & - & 0.04 & - \\
\hline 5: Unskilled (0/1) & 0.00 & - & 0.01 & - & 0.00 & - & 0.00 & - \\
\hline 6: Other $(0 / 1)$ & 0.01 & - & 0.02 & - & 0.01 & - & 0.01 & - \\
\hline Number of observations & \multicolumn{2}{|c|}{12692} & \multicolumn{2}{|c|}{4988} & \multicolumn{2}{|c|}{12692} & \multicolumn{2}{|c|}{4988} \\
\hline
\end{tabular}


In Table 2, summary statistics are presented separately for fathers and mothers in the control group (same sub-sector) and the treatment group (different sub-sectors). Couples in the treatment and control groups are relatively similar although there are some differences which should be corrected for by adding control variables in the empirical analysis. Couples in the treatment group are slightly more likely to live in a big city than couples in the control group. Most often it is the fathers in the treatment group who are employed in the state whereas the mothers are employed in the local municipality or local county. Couples in the control group are more often employed in the local municipality or local county. Wages and promotion patterns are slightly better in the treatment group. Fathers in the control group tend to take more leave, and they more often have a medium cycle higher education and less often a long cycle higher education, which makes sense as teachers and pedagogues constitute a large group of public employees in the local municipalities.

In Figure 3, the trends in leave taking in the control group and the treatment group are illustrated. For fathers, the trends in child leave are rather similar before the reform, and the treatment group really only takes off two years after the reform (that is in 2004). This is suspected to be due to a delayed response to the reform. For mothers, the average leave of the control group increases as a consequence of the reform, while for the treatment group it rises and then falls back to a slightly lower level two and three years after the reform (that is, in 2004 and 2005), which supports a delayed response as well. There are no other main reforms or changes in society in 2004 that could explain this pattern.

\section{Figure 3. Trends in child leave}
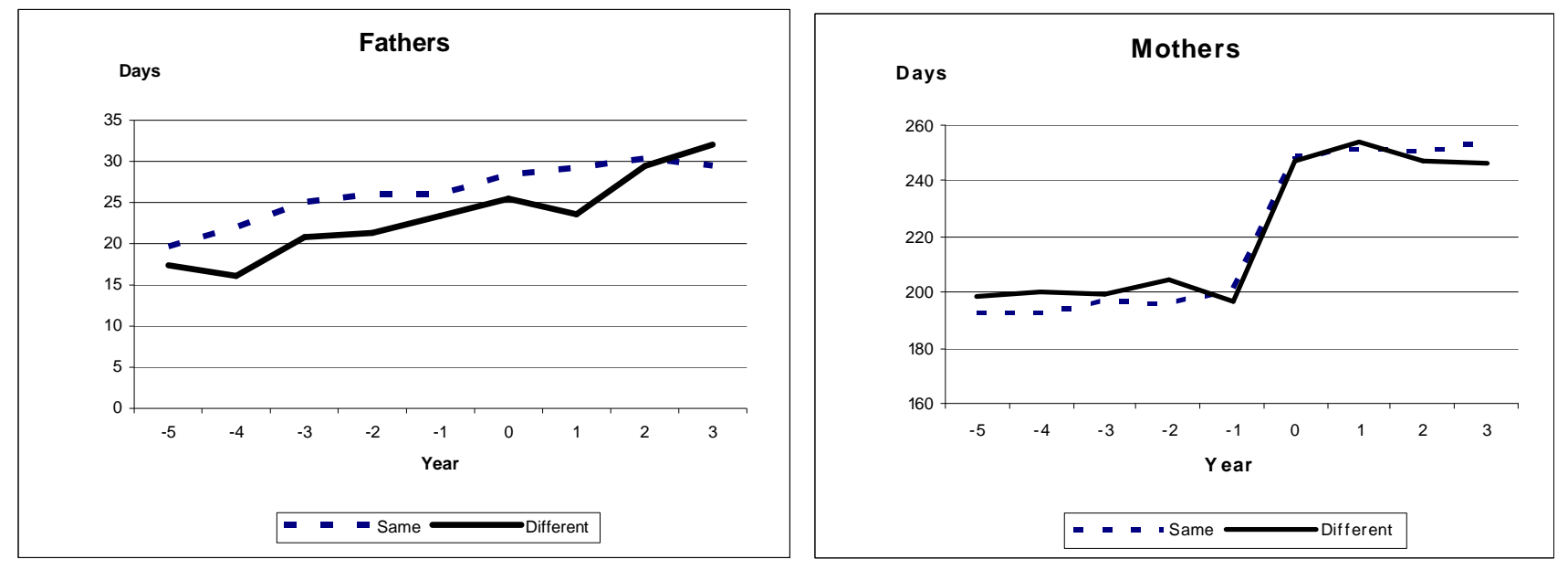

In Table 3, transition matrices for the couples' transitions between possible combinations of sub-sectors are shown. Panels $\mathrm{A}$ and $\mathrm{C}$ show the transition rates before birth for couples observed to have a child pre- and post-reform, respectively, whereas panels B and D show the transition rates after the birth for couples observed to have a child pre- and post-reform, respectively.

It is evident from the table that the transition rates before birth are literally unchanged before and after the reform. Thus, there is no evidence that couples select into the treatment group as a consequence of the reform. This makes perfect sense as switching from the control group to the treatment group would require a switch of job which would most likely be much more costly than the potential gain from the child leave scheme. Furthermore, for some individuals it would be difficult to switch group either 
because they reside outside Copenhagen and the biggest cities, where state employment is more prevalent, or because the employment possibilities depend on their education. The local municipalities are responsible for schools and daycare facilities, and thus they employ the dominant share of teachers and pedagogues, while the local counties are responsible for public hospitals and general practitioners and thus employ most of the health personnel.

When it comes to the period after the birth, it is seen in the table that the transition pattern changes slightly as an additional $10 \%$ of the couples in different sub-sectors transit to the same sub-sectors after the reform. It is not a tendency that challenges the main identifying assumption. ${ }^{12}$

\section{Table 3. Transition matrices}

\begin{tabular}{|c|c|c|c|c|c|c|c|c|c|c|}
\hline \multirow{4}{*}{$\begin{array}{l}\text { Period t-1 } \\
\text { Couple is employed in }\end{array}$} & \multicolumn{5}{|c|}{ A: Pre-reform (before birth) } & \multicolumn{5}{|c|}{ C: Post-reform (before birth) } \\
\hline & \multirow{2}{*}{\multicolumn{3}{|c|}{$\begin{array}{c}\text { Period t } \\
\text { Couple is employed in }\end{array}$}} & \multirow{2}{*}{\multicolumn{7}{|c|}{$\begin{array}{c}\text { Period t } \\
\text { Couple is employed in }\end{array}$}} \\
\hline & & & & & & & & & & \\
\hline & Same & Different & Other & All & Nobs & Same & Different & Other & All & Nobs \\
\hline$\overline{\text { Same }}$ & 0.915 & 0.029 & 0.056 & 1.000 & 6916 & 0.944 & 0.026 & 0.031 & 1.000 & 7276 \\
\hline Different & 0.069 & 0.864 & 0.068 & 1.000 & 2874 & 0.108 & 0.855 & 0.037 & 1.000 & 2731 \\
\hline Other combination & 0.401 & 0.171 & 0.428 & 1.000 & 5711 & 0.416 & 0.191 & 0.393 & 1.000 & 5149 \\
\hline \multirow[t]{2}{*}{ All } & 0.569 & 0.236 & 0.195 & 1.000 & 15501 & 0.614 & 0.231 & 0.155 & 1.000 & 15156 \\
\hline & \multicolumn{3}{|c|}{ B: Pre-reform (after birth) } & \multicolumn{7}{|c|}{ D: Post-reform (after birth) } \\
\hline Period t-1 & \multicolumn{3}{|c|}{ Couple is employed in } & \multicolumn{7}{|c|}{$\begin{array}{c}\text { Period t } \\
\text { Couple is employed in }\end{array}$} \\
\hline Couple is employed in & Same & Different & Other & All & Nobs & Same & Different & Other & All & Nobs \\
\hline Same & 0.794 & 0.025 & 0.182 & 1.000 & 9211 & 0.807 & 0.025 & 0.169 & 1.000 & 8242 \\
\hline Different & 0.047 & 0.738 & 0.215 & 1.000 & 3853 & 0.158 & 0.620 & 0.221 & 1.000 & 3075 \\
\hline Other combination & 0.248 & 0.114 & 0.638 & 1.000 & 2326 & 0.265 & 0.109 & 0.626 & 1.000 & 1115 \\
\hline All & 0.524 & 0.217 & 0.259 & 1.000 & 15390 & 0.598 & 0.180 & 0.223 & 1.000 & 12432 \\
\hline
\end{tabular}

Note: The pre-reform period is defined as 1997-2001, while the post-reform period is defined as 2002-2005. Each couple contribute with several observations. For instance, if the couple have two children in 1998 and 2000, they contribute with three observations to panel A $(1997 / 98,1998 / 99,1999 / 00)$ and three observations to panel B (1998/99, 1999/00, 2000/01).

In Table 4, couples are distributed by education type-level cells. For each cell, the proportion of treated couples is given. The average rate of treatment is $28 \%$, but the proportion varies considerably across the cells. For instance, the cell consisting of two pedagogues and teachers $(4,4)$ contains 4,351 couples, which is about one fourth of the sample, and these couples are rarely treated. Exactly the same is seen for another large group of male pedagogues or teachers (4) combined with female nurses (7). At the other extreme, couples consisting of a male with a long cycle higher education in social sciences (9) or in natural or technical sciences (10) combined with a female pedagogue, teacher or nurse (4 or 7) are treated more often than average. This table underlines the importance of controlling carefully for individuals', partners' and couples' level and type of education.

\footnotetext{
12 This tendency of couples to transit away from employment in different sub-sectors reflects that more males switch sector and that more first time parents switch sector after a birth after the reform compared to before the reform. If the pattern was due to the reform, one would have expected the opposite; namely that first time parents have an incentive to stay under different agreements until fertility is completed, while second and third time parents have an incentive to switch if they expect their fertility to be completed.
} 
Table 4. Proportions of couples employed in different sub-sectors across education cells

\begin{tabular}{|c|c|c|c|c|c|c|c|c|c|c|c|c|}
\hline \multirow{2}{*}{$\begin{array}{c}\text { Father's } \\
\text { education }\end{array}$} & \multicolumn{12}{|c|}{ Mother's education } \\
\hline & 1 & 2 & 3 & 4 & 5 & 6 & 7 & 8 & 9 & 10 & 11 & Total \\
\hline \multirow[t]{2}{*}{1} & 0.14 & 0.33 & 0.00 & 0.48 & 0.45 & 0.50 & 0.43 & 0.50 & 0.67 & 0.50 & 0.15 & 0.42 \\
\hline & 29 & 9 & 2 & 97 & 11 & 2 & 67 & 6 & 15 & 2 & 13 & 253 \\
\hline \multirow[t]{2}{*}{2} & 0.67 & 0.33 & 0.00 & 0.44 & 0.44 & 0.20 & 0.47 & 0.36 & 0.24 & 0.45 & 0.57 & 0.43 \\
\hline & 6 & 40 & 1 & 180 & 16 & 10 & 132 & 11 & 25 & 22 & 23 & 466 \\
\hline \multirow[t]{2}{*}{3} & 0.29 & 0.68 & 0.02 & 0.82 & 0.58 & 0.43 & 0.88 & 0.89 & 0.33 & 0.40 & 0.46 & 0.55 \\
\hline & 14 & 34 & 290 & 253 & 19 & 14 & 308 & 18 & 61 & 15 & 13 & 1039 \\
\hline \multirow[t]{2}{*}{4} & 0.22 & 0.31 & 0.80 & 0.05 & 0.18 & 0.30 & 0.06 & 0.23 & 0.39 & 0.45 & 0.42 & 0.08 \\
\hline & 18 & 32 & 5 & 4351 & 120 & 30 & 871 & 60 & 137 & 55 & 184 & 5863 \\
\hline \multirow[t]{2}{*}{5} & 0.50 & 0.33 & 1.00 & 0.29 & 0.20 & 0.33 & 0.32 & 0.22 & 0.34 & 0.36 & 0.38 & 0.29 \\
\hline & 8 & 6 & 1 & 156 & 133 & 3 & 105 & 9 & 32 & 11 & 34 & 498 \\
\hline \multirow[t]{2}{*}{6} & 0.22 & 0.38 & 0.00 & 0.56 & 0.48 & 0.25 & 0.57 & 0.65 & 0.31 & 0.37 & 0.49 & 0.50 \\
\hline & 9 & 26 & 3 & 268 & 33 & 72 & 323 & 46 & 72 & 49 & 55 & 956 \\
\hline \multirow[t]{2}{*}{7} & 0.00 & 0.25 & 1.00 & 0.08 & 0.10 & 0.33 & 0.03 & 0.19 & 0.56 & 0.11 & 0.32 & 0.08 \\
\hline & 3 & 8 & 2 & 146 & 20 & 3 & 557 & 21 & 27 & 9 & 22 & 818 \\
\hline \multirow[t]{2}{*}{8} & 0.75 & 0.27 & & 0.17 & 0.16 & 0.13 & 0.07 & 0.18 & 0.45 & 0.44 & 0.56 & 0.19 \\
\hline & 4 & 15 & 0 & 109 & 19 & 8 & 546 & 727 & 106 & 62 & 71 & 1667 \\
\hline \multirow[t]{2}{*}{9} & 0.18 & 0.40 & 0.00 & 0.50 & 0.37 & 0.60 & 0.52 & 0.54 & 0.29 & 0.44 & 0.43 & 0.41 \\
\hline & 17 & 15 & 2 & 414 & 106 & 25 & 423 & 165 & 854 & 115 & 264 & 2400 \\
\hline \multirow[t]{2}{*}{10} & 0.23 & 0.23 & 0.38 & 0.62 & 0.49 & 0.35 & 0.65 & 0.60 & 0.37 & 0.27 & 0.40 & 0.45 \\
\hline & 26 & 43 & 8 & 386 & 67 & 51 & 470 & 185 & 247 & 717 & 212 & 2412 \\
\hline \multirow[t]{2}{*}{11} & 0.08 & 0.33 & & 0.41 & 0.53 & 0.40 & 0.51 & 0.47 & 0.36 & 0.26 & 0.34 & 0.39 \\
\hline & 12 & 9 & 0 & 296 & 43 & 10 & 192 & 83 & 149 & 50 & 464 & 1308 \\
\hline \multirow[t]{2}{*}{ All } & 0.24 & 0.36 & 0.05 & 0.20 & 0.32 & 0.33 & 0.33 & 0.33 & 0.34 & 0.32 & 0.40 & 0.28 \\
\hline & 146 & 237 & 314 & 6656 & 587 & 228 & 3994 & 1331 & 1725 & 1107 & 1355 & 17680 \\
\hline
\end{tabular}

Note: Education groups are coded as follows: 1) SCHE SocSci, 2) SCHE NatTech, 3) SCHE PoliceArmy, 4) MCHE PedTeach, 5) MCHE SocSci, 6) MCHE NatTech, 7) MCHE Health, 8) LCHE Health, 9) LCHE SocSci, 10) LCHE NatTech, and 11) LCHE HumSci.

\section{Empirical analysis}

In this subsection, the results of the estimation of the impact of economic incentives on the fathers' use of parental leave are presented as well as the results of the estimation of the consequences of leavesharing on the subsequent career of both the father and the mother. 


\subsection{Estimating the effect of economic incentives on leave-taking}

As described earlier, a differences-in-differences identification strategy is applied when estimating the effect of economic incentives on leave-taking. The following equation is estimated separately for fathers and mothers:

$$
\text { Leave }_{i j}=\alpha+\beta_{0} \text { Post }_{i j}+\beta_{1} \text { Different }_{i j}+\beta_{2} \text { Post }_{i j} * \text { Different }_{i j}+\gamma X_{i j}+u_{i j}
$$

for child $j$ for individual $i$. The dependent variable Leave indicates the number of leave days, while the variable Post indicates whether the child birth is observed before or after the reform of the leave scheme, Different indicates whether the parents are employed in different sub-sectors of the public sector or in the same sub-sectors. The parameter of main interest is the coefficient to the interaction term between Post and Different, $\beta_{2}$. This parameter captures the effect of being treated with improved economic incentives inducing the father to take leave. Equation (1) is estimated by ordinary least squares (OLS) using total leave of either parent as a dependent variable. Furthermore, equation (1) is estimated by a tobit specification using parental leave as a dependent variable, while applying appropriate lower and upper limits to account for censoring and to capture the effects of treatment at the relevant leave margins. For fathers, a lower limit $(L L)$ of 0 days/0 weeks is applied and an upper limit $(U L)$ of 224 days/32 weeks is chosen to resemble the idea that the father is the marginal leave user. The estimation results are reported as marginal effects on expected leave, which counts both the effect on the latent leave demand and on the probability of entering the range of leave between $L L$ and $U L$. In the tobit regression for mothers, a lower limit of 70 days/10 weeks and an upper limit of 224 days/32 weeks are applied. ${ }^{13}$

After the reform, both parents were eligible for 10 weeks of paid parental leave at full wage compensation if they were in the treatment group, while only one of the parents could use the right to 10 weeks paid parental leave at full wage compensation if the couple was in the control group, and that parent would almost always be the mother. This is exactly what is picked up by the interaction term Post ${ }^{*}$ Diff. The amount of extra treatment measured in DKK is calculated as the father's labor income per day at child birth minus the daily benefit rate, this amount is denoted the CompGain, and as shown in Table 2, the average amount in the treatment group is DKK 469 (\$67). In some specifications, we include Post ${ }^{*}$ CompGain instead of the cross term effect (Post*Different), and furthermore, we also try to include the crude benefit-wage ratio, CompRate, instead of the cross term effect (Post*Different).

The vector of control variables, $X_{i j}$, includes year dummies (corresponding to Post), indicator variables for whether the child is the first, second or third or more, and indicator variables for whether the couple lives in a big city or not. Furthermore, the following variables for both partners are included: age, age squared, log wages (in 2006 prices), detailed indicators for the level and/or type of education, occupation. As an alternative to the education and occupation variables, fixed effects for couples' educational type-level cell indicators are included to account as precisely as possible for the pattern revealed in Table 4.

\footnotetext{
${ }^{13}$ Notice that these lower and upper limits closely correspond to the peaks seen in Figure 2. For fathers, the tobit specification treats the leave period as censored at 4 weeks of leave, for mothers, the tobit specification treats the leave period as censored at 24 weeks of leave.
} 
It is important to notice that the results should be interpreted conditional on being part of a welleducated, publicly employed couple. The estimate of $\beta_{2}$ may be seen as an upper bound on the effect of economic incentives on the father's usage of parental leave, because the sample is a selected sample of fathers who are in well-educated, publicly employed couples. First of all, public employers are most likely more supportive of fathers using the child leave scheme than the private employers (see Bygren and Duvander, 2006). In addition, well-educated couples are likely to have more equal gender role patterns than other couples, and well-educated and publicly employed fathers are likely to have higher preferences for child leave than other fathers (see Stafford and Sundström, 1996). In a US study, Han, Ruhm and Waldfogel (2009) find that well-educated fathers are more likely to respond to changes in their leave policy. Furthermore, it is expected that well-educated couples are more likely to be informed of the changes. However, it is still only the "effect of the intention to treat", as not all couples and their employers may be aware of the treatment.

In the appendix, the full sets of coefficient estimates from estimation of equation (1) for fathers and mothers are presented. They generally confirm the expectations. Both fathers and mothers take more leave after the reform. Fathers and mothers in local municipalities and counties take more leave than otherwise similar individuals employed in the state. The duration of leave increases by age up to a point. The duration of leave for the father is highest for the first child, and it is higher for the second child than for the third and higher ranked children, while the pattern is the other way around for the mother. Both mothers and fathers use more leave in relation to a twin birth.

The duration of leave is longer for fathers and mothers with a medium cycle higher education than it is for those with a short cycle higher education (the reference group), which is again higher than it is for those with a long cycle higher education. Own log wages have significant effects on leave-taking, but the sign is negative in the tobit specification. Below the focus is on the parameter of main interest, which is discussed in detail.

In Table 5, the result of the estimation of equation (1) for fathers and mothers is presented. With no controls (column 1), the effect of interest is 2.6 meaning that fathers in the treatment group increased their child leave by 2.6 days (from an average of 9.5 days) after being exposed to increased economic compensation for leave taking. Mothers reduce their leave taking correspondingly. This effect goes down to 2.2 when control variables are included in the estimation. It makes no difference for the parameter of main interest which of the descriptions of the skill match of the couple is used in columns $2-5$, although when education cell $*$ year fixed effects are added in column 6 , the estimates become more imprecise. Thus, it is concluded that the indicator for being employed in different sub-sectors does not only reflect the couple's specific educational match. If that was the case, it would question the validity of the common trend assumption as preferences for leave are likely to vary with the couples' specific educational match.

To investigate a potential delayed response, the effect of Different*Post is estimated separately for the years 2002-3 and 2004-5, see Table A2. The point estimate of the effect of improved economic incentives is higher for fathers in 2004-5 (3.5) compared to the benchmark case (2.6), while the point estimate in 2002-3 is not significantly different from zero. This indicates that the effect increases as the couples and the employers get to know the reform, and as a consequence, the true effect of economic incentives is most likely closer to the long-run response than to the benchmark estimate. 
Table 5. Estimation of the effect of economic incentives on fathers' and mothers' leave taking

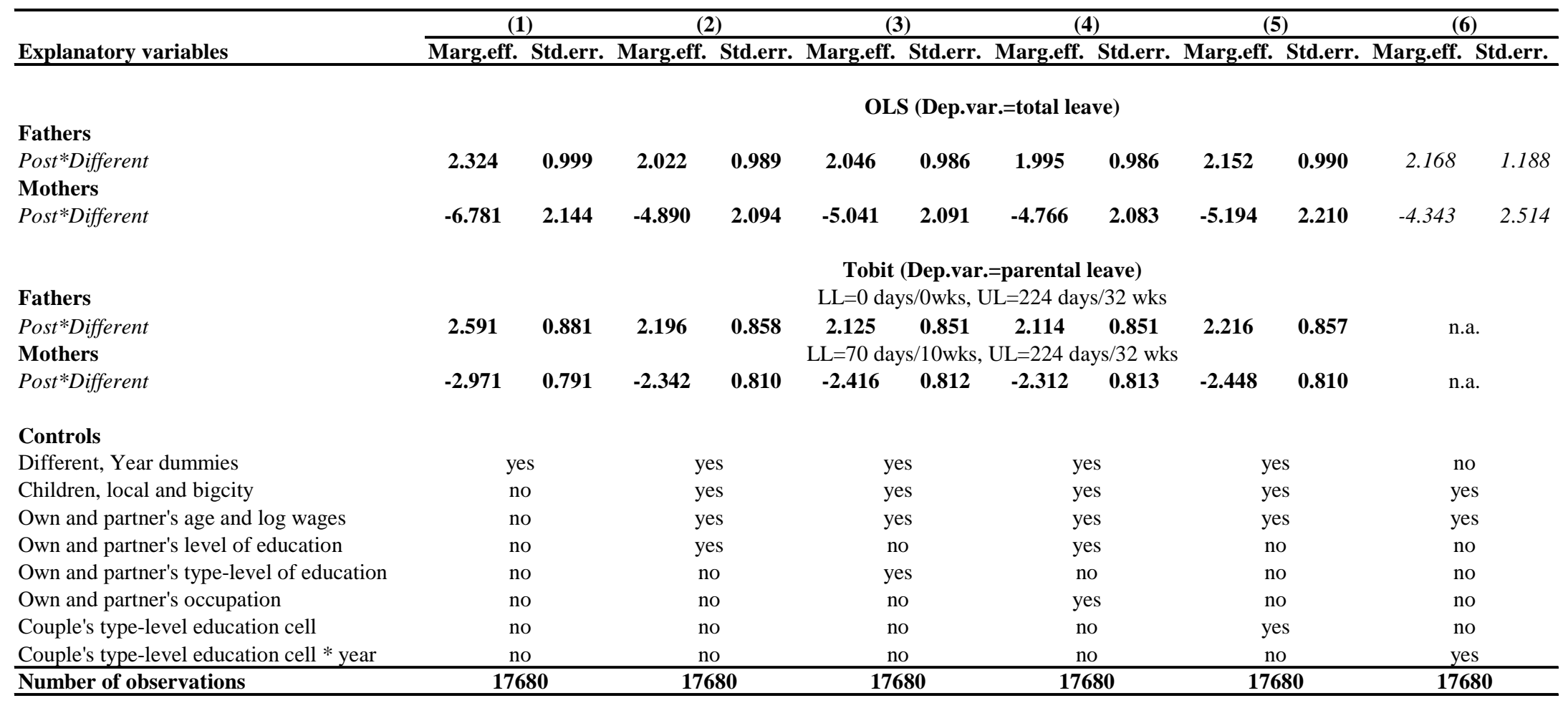

Note: Bold letters indicate significance at a 5\%-level, while italics indicate significance at a $10 \%$-level. N.a. indicates that the Tobit estimates are not available in this case as neither the fixed effects nor dummy variable model are estimable. 
Running the same regressions with the father's share of the couple's leave and the mother's share of the couple's leave suggest that the treatment induced couples to transfer 1 percent of the leave period from the mother to the father. ${ }^{14}$

Inference in a difference-in-differences specification like this should account for clustering. Donald and Lang (2007) examine inference in difference-in-difference analysis and suggest that one draws inference on confidence bands based on t statistics with fewer degrees of freedom which accounts for the clustering problem. In the present case, we have six degrees of freedom in the baseline specification in column (1) corresponding to a t-statistic of 2.447 at a 5\%-level and 1.943 at a $10 \%$-level. This would render the OLS estimates insignificant at a 5\%-level (but significant at the 10\%-level), while the tobit estimates would still be significant at the 5\% level. Vikström (2009) suggests a sensitivity analysis which analyzes whether inference is sensitive to the variance of the cluster effects. Conclusions are unchanged if one allows for a cluster variance corresponding to what is seen in the raw data.

In Table A3 in the appendix, the results for the sample of all public employees are shown. This sample includes both the 17,680 highly educated couples from the previous analysis as well as the individuals who completed only lower or upper secondary school. For this sample, the fathers respond less to economic incentives, and the effect is only significant in the tobit model and not in the OLS estimations. In the tobit model, the fathers increase their leave period by 1.2 days (from an average of 8.4) as a response to the improved economic incentives. The mother's reduction in leave due to improved economic incentives to let the father take the leave is of the same magnitude, but it is not statistically significant. Focusing on the long run response (column 4), the effects are similar in the OLS and the tobit model, and the fathers respond by a 2.5 day increase and the mothers respond by a similar reduction which is now borderline significant ( $\mathrm{p}$-value slightly over $10 \%$ ). Thus the fathers take more leave due to improved economic incentives, but the response of the mothers is not as precisely estimated as for the well-educated sample. However, the point estimates indicates that the economic incentives induced a transfer of leave from the father to the mother of about 2.5 days in the long run.

The next step is to reinterpret the finding of a strong effect of economic incentives into more policy relevant figures, that is, money equivalents and elasticities. In Figure 4, the distribution of the compensation gains for the 2590 treated fathers who are observed post reform is illustrated. The mean gain is DKK 480 (347) while it reaches DKK 496 (315) if the negative values are replaced by zeros.

\footnotetext{
${ }^{14}$ If the share of total leave is used as the dependent variable, this number is .8 percent, while it is 1.2 percent if the share of parental leave is used as the dependent variable.
} 
Figure 4. Distribution of the compensation gain per day for treated fathers (in 2006 DKK)

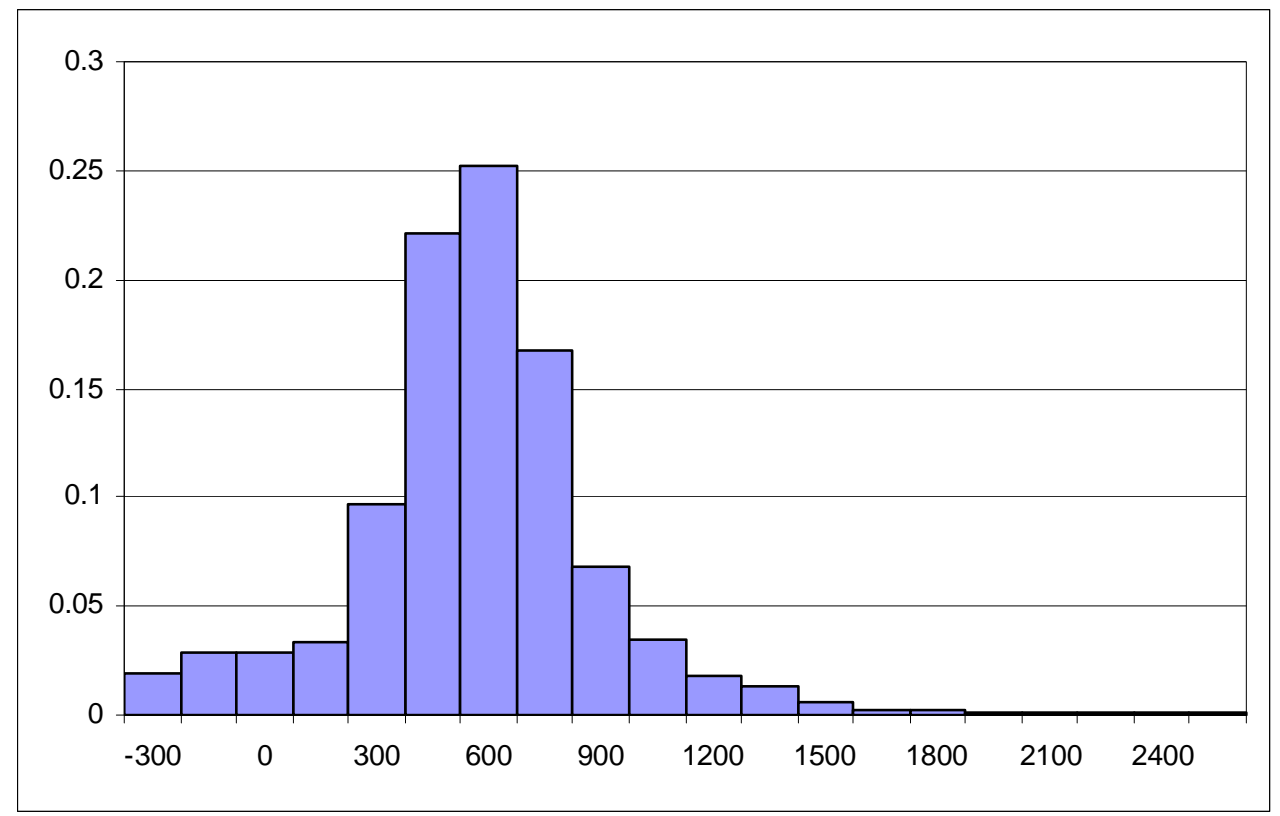

In columns (1) and (2) in Table 6, the Post*CompGain as well as a quadratic term are included instead of Post*Diff to obtain a parameter measured in money terms. The resulting quadratic profile is illustrated in Figure 5. At the mean gain of DKK 496 per day (\$71), leave usage is increased by 2.8 days, meaning that the father increases leave taking by one day when compensation is improved by DKK 175 per day (\$25). If we deduct taxes, a transfer of one day from the father to the mother may be achieved by increasing net compensation by DKK $65(\$ 9)$. The elasticity of child care supply is thus as high as .94 using the net compensation, ${ }^{15}$ and the effect of economic incentives inducing the fathers to take leave is extremely high.

For the sample of all public employees, the response is somewhat lower. A 400 DKK (\$57) increase in gross compensation gain corresponding to a DKK 148 (\$21) increase in net gain is needed to increase leave usage by one day. This results in an elasticity of .44 using net compensation, which is still a high number though.

In columns (2) and (3), a crude measure of the benefit-wage ratio (CompRate) is included instead of Post*Diff to interpret the magnitude of the effect of economic incentives. The effect of an increase in the benefit-wage ratio by ten percentage points is estimated to be around 2 days, and it is very precisely estimated.

\footnotetext{
${ }^{15}$ The elasticity is computed as $(2.82 / 9.54) /((1-.63) * 496 /((1-.4) * 972))=.94$, where 9.54 is the average duration of parental leave, DKK 496 is the average compensation gain per day, DKK 972 is the average labor income per day, while .63 and .40 are the marginal and average tax rates in the relevant tax bracket.
} 
Table 6. Estimation of the effect of economic incentives on fathers' usage of parental leave

\begin{tabular}{|c|c|c|c|c|c|c|c|c|}
\hline \multirow[b]{2}{*}{ Explanatory variables } & \multicolumn{2}{|c|}{ (1) } & \multicolumn{2}{|c|}{ (2) } & \multicolumn{2}{|c|}{ (3) } & \multicolumn{2}{|c|}{ (4) } \\
\hline & Marg.eff. & Std.err. & Marg.eff. & Std.err. & Marg.eff & Std.err. & Marg.eff. & Std.err. \\
\hline & \multicolumn{8}{|c|}{ Tobit (Dep.var.=parental leave) } \\
\hline Post ${ }^{*}$ CompGain (/100) & 1.024 & 0.250 & 1.009 & 0.249 & & & & \\
\hline Post ${ }^{*}$ CompGainSqr (/10000) & -0.092 & -0.024 & -0.094 & -0.024 & & & & \\
\hline CompRate & & & & & 20.617 & 1.916 & 18.541 & 1.920 \\
\hline Controls & & & & & & & & \\
\hline Different, Year dummies & \multicolumn{2}{|c|}{ yes } & \multicolumn{2}{|c|}{ yes } & \multicolumn{2}{|c|}{ yes } & \multicolumn{2}{|c|}{ yes } \\
\hline Children, local and bigcity & \multicolumn{2}{|c|}{ yes } & \multicolumn{2}{|c|}{ yes } & \multicolumn{2}{|c|}{ yes } & \multicolumn{2}{|c|}{ yes } \\
\hline Own and partner's age and log wages & \multicolumn{2}{|c|}{ yes } & \multicolumn{2}{|c|}{ yes } & \multicolumn{2}{|c|}{ yes } & \multicolumn{2}{|c|}{ yes } \\
\hline Own and partner's level of education & \multirow{2}{*}{\multicolumn{2}{|c|}{$\begin{array}{c}\text { yes } \\
\text { no }\end{array}$}} & \multirow{2}{*}{\multicolumn{2}{|c|}{ no }} & \multirow{2}{*}{\multicolumn{2}{|c|}{ yes }} & \multicolumn{2}{|c|}{ no } \\
\hline Own and partner's type-level of education & & & & & & & & es \\
\hline Number of observations & \multicolumn{2}{|c|}{17680} & \multicolumn{2}{|c|}{17680} & \multicolumn{2}{|c|}{17680} & \multicolumn{2}{|c|}{17680} \\
\hline
\end{tabular}

Note: Bold letters indicate significance at a 5\%-level, while italics indicate significance at a $10 \%$-level.

Figure 5. Illustration of the quadratic effect of the compensation gain on fathers' leave usage.

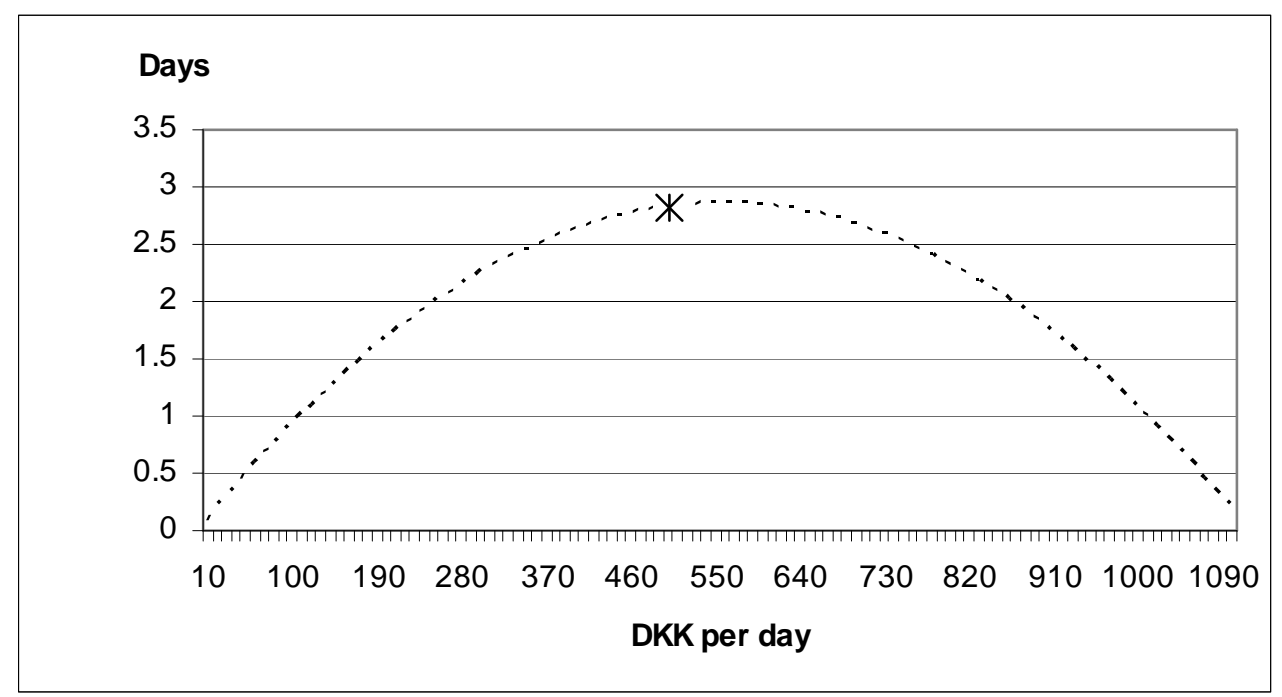

\subsection{Heterogeneous treatment effects ${ }^{16}$}

In this sub-section, results from separate estimations by sub-groups are summarized. The effects vary widely, and it seems that couples where the mother is relatively career-minded and the father is less career-minded apparently respond more to economic incentives than others. Details follow below.

\footnotetext{
${ }^{16}$ Estimation results by sub-group are available from the author upon request.
} 
The effect of economic incentives inducing couples to shift leave from the mother to the father is largest for partners in couples with a medium cycle higher education, and it is particularly large if the father's field of education is social sciences, or if the mother is in the group of teachers and pedagogues. The effects are also significant for partners who have a long cycle higher education within social sciences. Focusing on the rank of the child, the effect of economic incentives inducing the couple to transfer leave from the mother to the father tends to be larger for the first child than for following children.

The changes in leave usage as a consequence of inducing the father to take leave are larger for mothers who are occupied in high-level salaried jobs, and for fathers who are occupied in low-level salaried job. Furthermore, the effects tend to be driven by couples living in big cities and by couples where the father is employed by the local government while the mother is employed by the state rather than the opposite.

\subsection{Validity checks}

The main methodological concern is whether the common trend assumption is valid. This assumption is not testable, but a number of checks can be implemented to ascertain that it holds.

One concern is that couples employed in different sub-sectors of the public sector are systematically different from those employed in the same sub-sector in terms of preferences for fathers to take part of the leave. To account for this, detailed controls for the individual's and the partner's education and the couple's combination of educations have been included as these variables are thought to pick up variation in leave preferences across individuals and couples. Furthermore, education cell * year fixed effects have been included. As discussed in the previous sub-sections, the results are robust to the inclusion of such variables.

An often used approach to test the common trend assumption is to introduce a "fake reform". Based on the implementation of a fake reform in year 2000, it is found that the coefficient to the parameter of interest becomes insignificant when estimating equation (1) based on pre-reform data; see Table A4 in the appendix. This indicates that the parameter of main interest does not just pick up the effect of a difference in pre-existing trends in child leave.

Another concern is that couples employed in different sub-sectors to some extent have coordinated their choice of employers because they would like to make use of the generous leave conditions for fathers. Below, this concern is dismissed by use of a few estimation checks.

First of all, it is unlikely that the couples are aware of the extraordinarily generous leave conditions for fathers until they have been exposed to the child leave regulations themselves. Therefore, the fact that couples are more responsive to the reform when they have their first child than when they have further children supports the assumption that the effect is not a consequence of self-selection into treatment.

As a second test of the identifying assumption, the indicator for whether the couple is employed in different versus same sub-sector is defined based on the employment relationship in 2001 (that is, before the reform). This indicator variable is highly correlated with the actual treatment, but it cannot be influenced by "selection into treatment". ${ }^{17}$ In these estimations, the parameter of main interest is

\footnotetext{
${ }^{17}$ This argument to avoid selection into treatment was also applied by Currie and Moretti (2003) and Black et al. (2005).
} 
also statistically significant in the tobit specification (results not reported). However, as expected, these results are noisier because the distinction between the treatment and the control group becomes less precise.

\subsection{Estimating the effect of leave-taking on career outcomes}

In this sub-section, it is analyzed whether leave taking has an impact on post-birth earnings and promotion. Table 7 shows the results of the estimation of the effect of leave on career outcomes. From OLS and probit regressions, it is seen that the association between leave and career outcome is strong and negative in particular for mothers. However, these estimates are most likely flawed by endogeneity bias as the parents who take a long leave may be systematically less likely to have a large earnings potential and a high degree of career commitment. When the potentially endogenous effect of leave on career outcome is instrumented, the effects are not as clear.

\section{Table 7. Estimation of the effect of child leave on career outcomes}

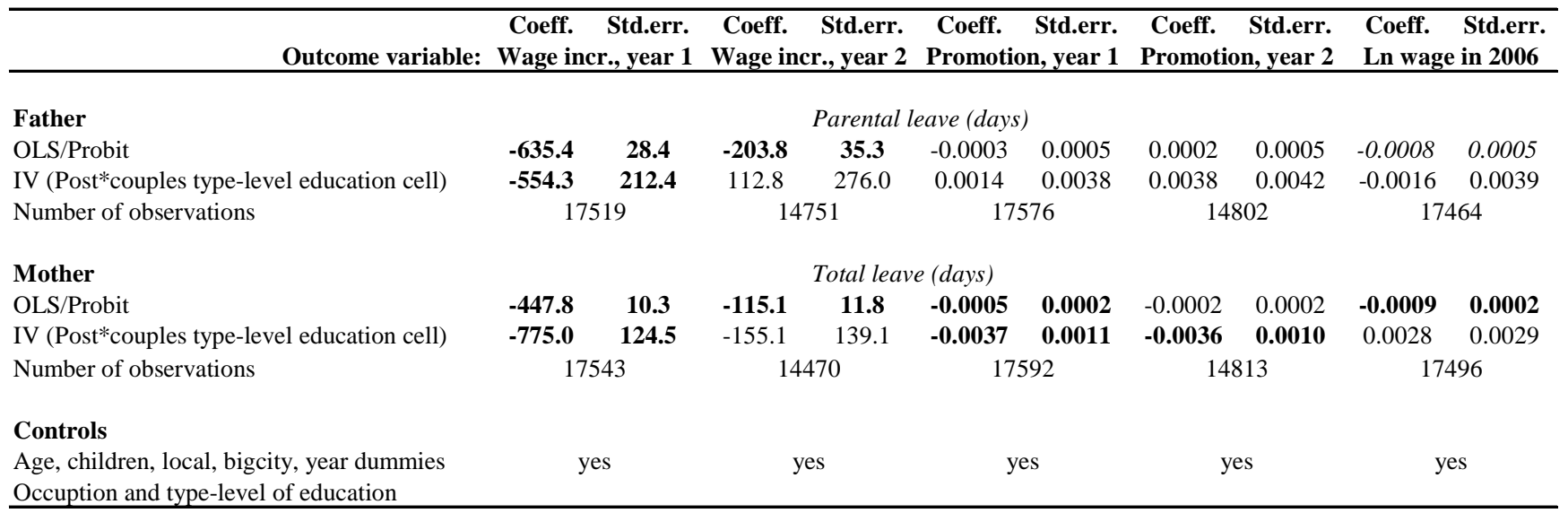

Note: Bold letters indicate significance at a 5\%-level, while italics indicate significance at a 10\%-level.

The variable Post ${ }^{*}$ Different is not quite strong enough to work well as an instrumental variable. Instead indicator variables for the couples' type-level education cells are used as instrumental variables. Thus, the variation in Different visible in Table 4 is used for instrumentation of leave taking. This approach indicates a weak or non-existing causal impact of leave on the father's wages and promotion, while it indicates a negative impact of leave on the mother's wages and promotion. The reason for this gender difference is most likely the fact that the father's leave period is very short on average, while the mother's leave period is substantively longer and therefore makes it easier to detect a potential negative impact. For mothers, a one day increase in leave results in a DKK 775 lower increase in annual wages in the first year after birth, and a DKK 155 lower increase in annual wages two years after. This pattern is consistent with experience foregone during child leave and subsequent catch up. A similar wage pattern is seen for fathers. For mothers, an increase in leave depresses the promotion probability, whereas no effect is found for fathers. 


\section{Conclusion}

During the last couple of decades, several OECD countries have tried to induce more fathers to take longer parental leave by reserving some weeks of leave for the fathers or by improving their compensation rate (OECD, 2007). However, the take-up rate is relatively low and the fathers' share of the total leave is relatively low even in the Nordic countries where some of the most generous conditions are seen. In the Nordic countries the fathers' share of the total leave ranges from $31 \%$ in Iceland to around $15 \%$ in Sweden and Norway to 5\% in Finland (Datta Gupta, Smith and Verner, 2008). In this study, the proportion for Denmark is found to be around $10 \%$.

This paper investigates the importance of economic incentives for publicly employed fathers' usage of parental leave schemes. An extensive reform of child leave schemes in Denmark in 2002 affected publicly employed couples differently depending on which combination of sub-sectors they were employed in. Based on a differences-in-differences strategy, I find that economic incentives are extremely important for the fathers' usage of parental leave schemes. The average couple in the sample transferred 2.6 days from the father to the mother as a consequence of the improved economic incentives to let the father use the leave. In money terms, this means that increasing the couples' after tax income by $\$ 9$ per day of leave which is transferred from the mother to the father is found to increase the fathers' leave usage by one day. This corresponds to an elasticity of almost unity.

Judging from the results of this paper, which, admittedly, are based on publicly employed couples, the most promising strategy to increase fathers' leave usage would be to increase individual entitlement to paid leave in order to incentivize fathers to take leave independently of the mother's decision. This is exactly what OECD (2007) recommends. A fully individualized system is implemented in Iceland, where the total statutory paid leave is 9 months -3 months exclusively for the mother, 3 months exclusively to the father and 3 months to be shared between the parents. To a lesser extent, with a lower weight on the father's part of the leave, this is implemented in Sweden and Norway. In Denmark, the development goes in the same direction. The state guarantees paid leave for 52 weeks compensated at the UI-benefit level - 18 weeks exclusively to the mother, 2 weeks exclusively to the father and 32 weeks to be shared between the parents. However, the collective agreements increasingly incorporates individual entitlement to full uncapped wage compensation during parental leave periods, which means that the father independently of the mother gets the right to full pay for a certain part of the parental leave. These new agreements give the couple a stronger economic incentive to share the leave between them. Given that the aim is to get more fathers to take part of the parental leave, this study is supportive of the changes of the collective agreements in direction of an extension of the father's individual entitlement. ${ }^{18}$ However, it gives no answer as to whether these types of policies are welfare improving from the point of view of society or not.

\footnotetext{
${ }^{18}$ However, it is not advisable that the collective agreements extend rights to periods of paid leave to be shared between the parents. Such rights should relate to eligibility and not to compensation. These periods would most often be used by the mother, and furthermore, it results in discrimination against couples with the same employer without serving a well-defined political, economical or financial purpose.
} 


\section{References}

Albrecht, J. W., P.-A. Edin, M. Sundström and S. B. Vroman (1999), "Career Interruptions and Subsequent Earnings: A Reexamination Using Swedish Data." Journal of Human Resources 34(2): 294-311.

Bergemann, A. and R. T. Riphahn (2009), "Female Labor Supply and Parental Leave Benefits: The Causal Effect of Paying High Transfers for a Shorter Period of Time." IZA DP 3982. IZA, Bonn.

Black, S., Devereux, P. and K. Salvanes (2005), "Why the Apple Doesn't Fall Far: Understanding the Intergenerational Transmission of Education." American Economic Review 95 (1): 437-449.

Bygren, M. and A-Z. Duvander, (2006). "Parents' Workplace Situation and Fathers' Parental Leave Use", Journal of Marriage and Family, 68: 363-372

Currie, J. and E. Morretti (2003), "Mother's Education and the Intergenerational Transmission of Human Capital: Evidence From College Openings." Quarterly Journal of Economics 118 (4): 14951532.

Datta Gupta, N., N. Smith and M. Verner (2008), “The impact of Nordic countries' family-friendly policies on employment, wages and children." Review of Economics of the Household 6 (1) 65-89.

Donald, S. G. and K. Lang (2007), "Inference with Difference-in-Differences and Other Panel Data." Review of Economics and Statistics 89 (2) 221-233.

Ekberg, J., R. Eriksson, and G. Friebel (2005), "Parental Leave - A Policy Evaluation of the Swedish 'Daddy-Month' Reform” IZA DP 1617, Bonn.

Eriksson, R. (2005), "Parental Leave in Sweden: The Effects of the Second Daddy Month" SOFI WP\# 2005/9.

Han, W.-J., C. Ruhm, and J. Waldfogel (2009), Parental Leave Policies and Parents' Employment and Leave-Taking. Journal of Policy Analysis and Management 28 (1) 29-54.

Haas, L., K. Allard and P. Hwang, (2002), “The Impact of Organizational Culture on Men's Use of Family Leave Benefits in Sweden", Family Relations, 44, 28-36.

Hyde, J.S., Essex, M.J., and Horton, F. (1993), "Fathers and Parental Leave: Attitudes and Experiences" Journal of Family Issues 14: 616-638.

Hyde, J.S., \& Peterson, J.L. (2007). Parental Leave. In M. Haith \& J. Benson (Eds.), Encyclopedia of infant and early childhood development. Elsevier.

Lammi-Taskula, J. (2007), Parental Leave for Fathers? Gendered Conceptions and Practices in Families with Young Children in Finland. Stakes: Helsinki.

Nepomnyaschy, L. and J. Waldfogel (2007), "Paternity Leave and Fathers' Involvement with Their Young Children: Evidence from the ECLS-B." Community, Work, and Family 10(4): 425-451.

Nielsen, H. S., M. Simonsen and M. Verner (2004), "Does the Gap in Family-friendly Policies Drive the Family Gap?“" Scandinavia Journal of Economics 26: 721-744.

OECD (2007), "Babies and Bosses: Reconciling Work and Family Life. A synthesis of findings for OECD Countries. OECD, Paris. 
Olsen, B. M. (2007), "Evalueringen af den Fleksible Barselsorlov", SFI Rapport 07:29, SFI, Copenhagen.

Pettit, B. and J. Hook (2005), "The Structure of Women's Employment in Comparative Perspective." Social Forces 84 (2): 779-801.

Pylkkänen, E. and N. Smith (2003), "Career Interruptions Due to Parental Leave: A Comparative Study of Denmark and Sweden". OECD Working Paper.

Rasmussen, A. W. (forthcoming), "Increasing the Length of Parents' Birth-Related Leave: The Effect on Children's Long-Term Educational Outcomes. Forthcoming in Labour Economics.

Statistics Denmark (2001), Nyt fra Danmarks Statistik: Dagpenge ved sygdom eller f $\phi$ dsel 2000.

Statistics Denmark (2006), Statistisk 10-års oversigt (In English: Statistical 10-year review 2006). Statistics Denmark.

Vikström, J. (2009), "Cluster sample inference using sensitivity analysis: The case with few groups.” Manuscript U of Uppsala. 
Appendix 1. Supplementary empirical evidence

Figure A1. Average child leave during 1994-2005

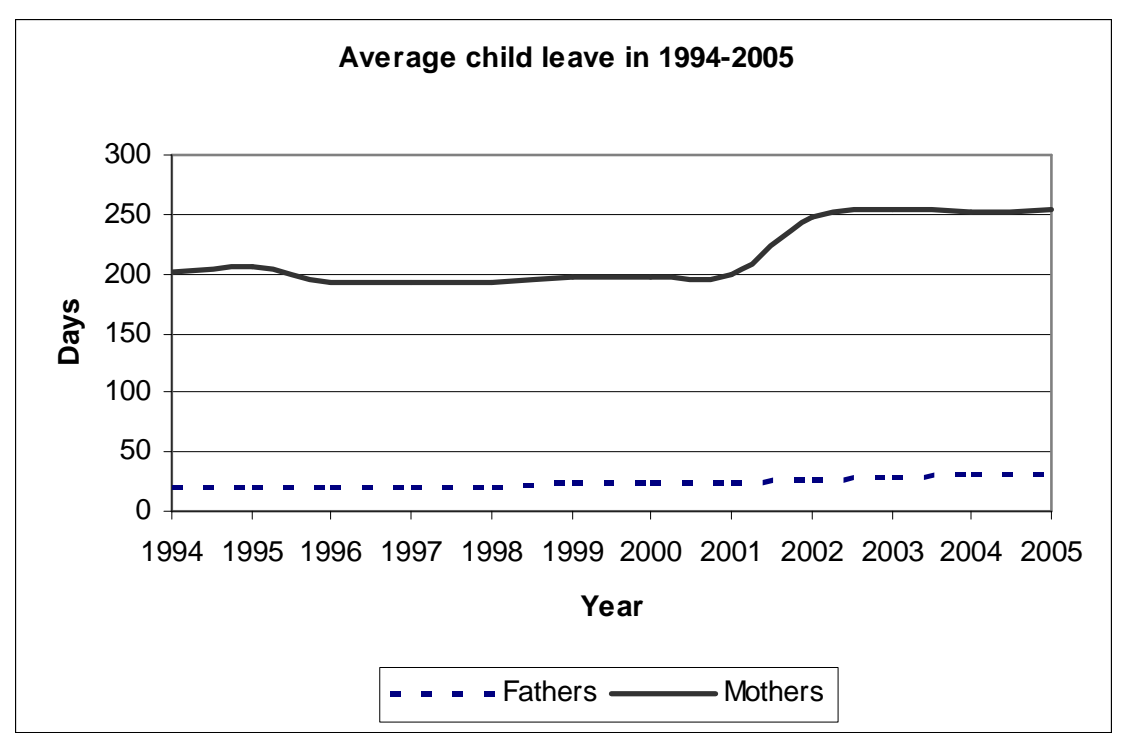

Figure A2. Leave-sharing during 1994-2005

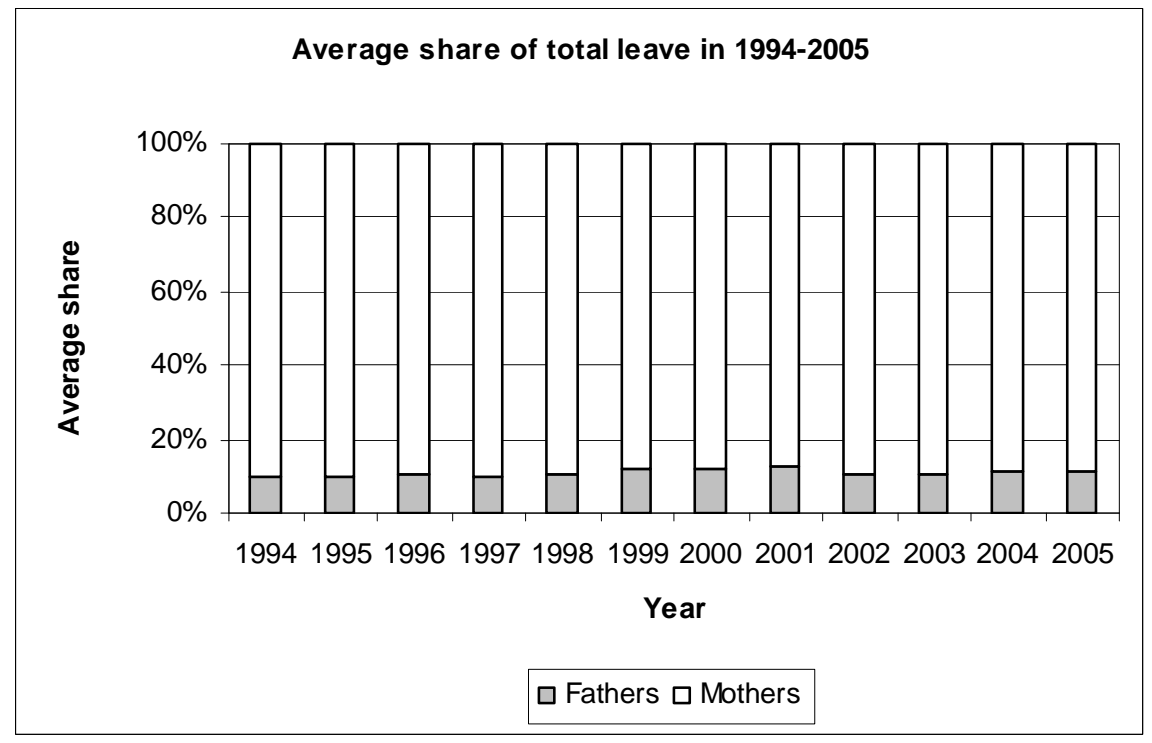


Table A1. Estimation of the effect of economic incentives on parents' leave taking (OLS and tobit)

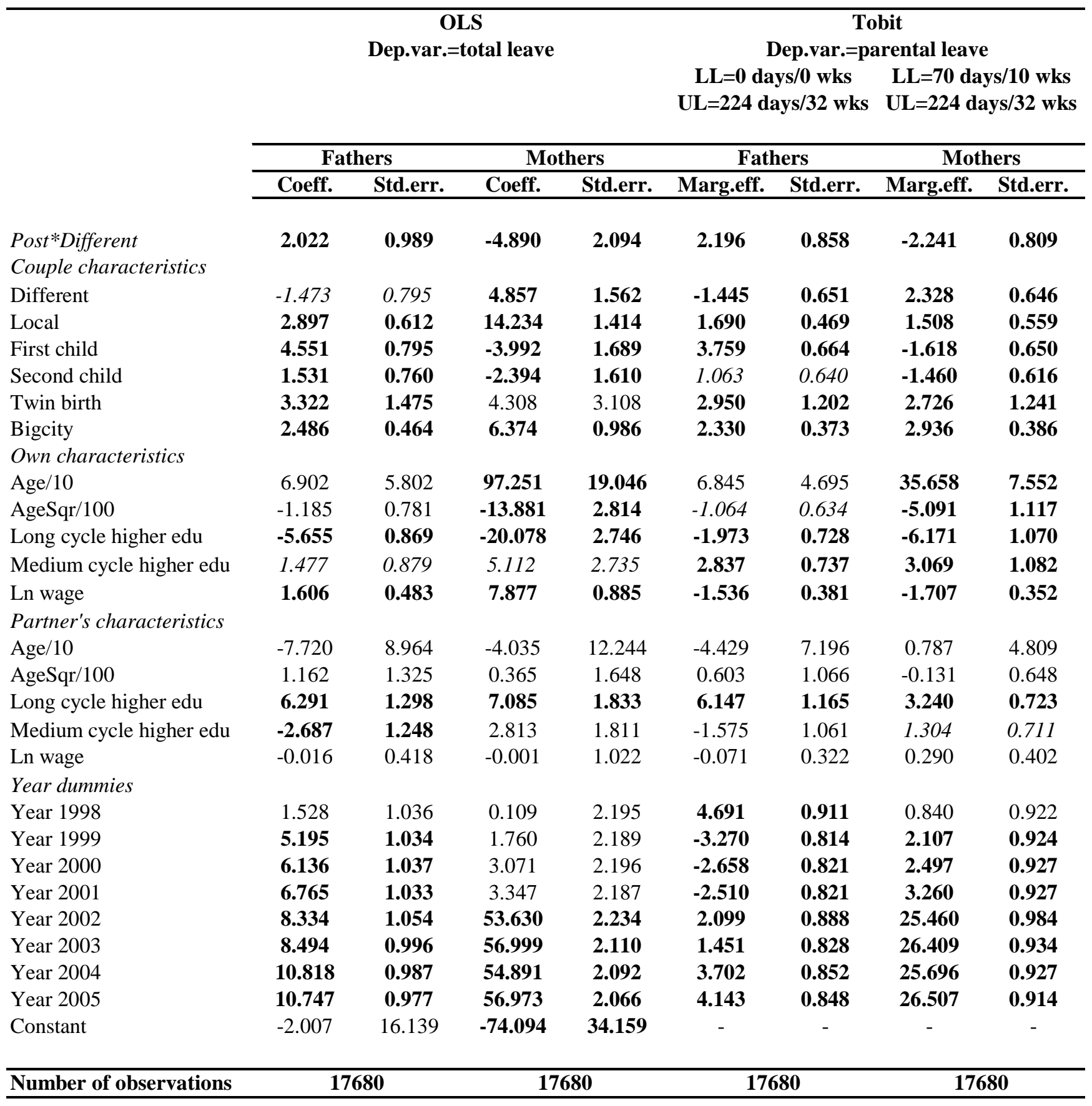

Note: Bold letters indicate significance at a 5\%-level, while italics indicate significance at a $10 \%$-level. 
Table A2. Estimation of the effect of economic incentives on father's and mother's leave taking. Delayed response

\begin{tabular}{|c|c|c|c|c|c|c|}
\hline \multirow[b]{3}{*}{ Explanatory variables } & \multicolumn{2}{|c|}{ (1) } & \multicolumn{2}{|c|}{ (2) } & \multicolumn{2}{|c|}{ (3) } \\
\hline & \multicolumn{2}{|c|}{ Benchmark } & \multicolumn{2}{|c|}{ Delayed response } & \multicolumn{2}{|c|}{ Delayed response } \\
\hline & Marg.eff. & Std.err. & Marg.eff & Std.err. & Marg.eff. & Std.err. \\
\hline & \multicolumn{6}{|c|}{ OLS (Dep.var.=total leave) } \\
\hline \multicolumn{7}{|l|}{ Fathers } \\
\hline Post $*$ Different & 2.022 & 0.989 & & & & \\
\hline Year $2002-2003 *$ Different & & & -0.762 & 1.244 & -1.042 & 1.528 \\
\hline Year $2004-2005 *$ Different & & & 4.287 & 1.164 & 4.422 & 1.366 \\
\hline \multicolumn{7}{|l|}{ Mothers } \\
\hline Post*Different & -4.890 & 2.094 & & & & \\
\hline Year $2002-2003 *$ Different & & & -2.220 & 2.634 & -1.335 & 3.236 \\
\hline \multirow[t]{2}{*}{ Year $2004-2005 *$ Different } & & & -7.066 & 2.466 & -6.458 & 2.893 \\
\hline & \multicolumn{6}{|c|}{ Tobit (Dep.var.=parental leave) } \\
\hline Fathers & \multicolumn{6}{|c|}{$\mathrm{LL}=0$ days $/ 0 \mathrm{wks}, \mathrm{UL}=224$ days $/ 32 \mathrm{wks}$} \\
\hline Post*Different & \multicolumn{6}{|c|}{0.881} \\
\hline Year $2002-2003 *$ Different & & & 0.456 & 1.045 & \multicolumn{2}{|c|}{ n.a. } \\
\hline Year $2004-2005 *$ Different & & & 3.497 & 1.017 & n.a & \\
\hline Mothers & \multicolumn{6}{|c|}{$\mathrm{LL}=70$ days $/ 10 \mathrm{wks}, \mathrm{UL}=224$ days $/ 32 \mathrm{wks}$} \\
\hline Post*Different & \multicolumn{6}{|c|}{$-2.9710 .791$} \\
\hline Year $2002-2003 *$ Different & & & -1.527 & 1.009 & n.a & \\
\hline Year $2004-2005 *$ Different & & & -3.003 & 0.941 & n.a & \\
\hline \multicolumn{7}{|l|}{ Controls } \\
\hline Different, Year dummies & \multicolumn{2}{|c|}{ yes } & \multicolumn{2}{|c|}{ yes } & \multicolumn{2}{|c|}{ no } \\
\hline Children, local and bigcity & \multicolumn{2}{|c|}{ yes } & \multicolumn{2}{|c|}{ yes } & \multicolumn{2}{|c|}{ yes } \\
\hline Own and partner's age and log wages & \multicolumn{2}{|c|}{ yes } & \multicolumn{2}{|c|}{ yes } & \multicolumn{2}{|c|}{ yes } \\
\hline Own and partner's level of education & \multicolumn{2}{|c|}{ yes } & \multicolumn{2}{|c|}{ yes } & \multicolumn{2}{|c|}{ no } \\
\hline Couple's type-level education cell * year & \multicolumn{2}{|c|}{ no } & \multicolumn{2}{|c|}{ no } & yes & \\
\hline Number of observations & & 80 & & & $\overline{1768}$ & \\
\hline
\end{tabular}

Note: Bold letters indicate significance at a 5\%-level, while italics indicate significance at a $10 \%$-level. N.a. indicates that the Tobit estimates are not available in this case as neither the fixed effects or dummy variable model are estimable. 
Table A3. Estimation of the effect of economic incentives on father's and mother's leave-taking. All public employees

\begin{tabular}{|c|c|c|c|c|c|c|c|c|}
\hline \multirow[b]{2}{*}{ Explanatory variables } & \multicolumn{2}{|c|}{ (1) } & \multicolumn{2}{|c|}{ (2) } & \multicolumn{2}{|c|}{ (3) } & \multicolumn{2}{|c|}{ (4) } \\
\hline & Marg.eff. & Std.err. & Marg.eff. & Std.err. & Marg.eff. & Std.err. & Marg.eff. & Std.err. \\
\hline & \multicolumn{6}{|c|}{ OLS (Dep.var.=total leave) } & & \\
\hline \multicolumn{9}{|l|}{ Fathers } \\
\hline Post ${ }^{*}$ Different & 1.016 & 0.692 & 0.740 & 0.685 & 0.819 & 0.684 & & \\
\hline Year 2002-2003*Different & & & & & & & -1.199 & 0.861 \\
\hline Year 2004-2005*Different & & & & & & & 2.559 & 0.840 \\
\hline \multicolumn{9}{|l|}{ Mothers } \\
\hline Post*Different & -2.459 & 1.603 & -1.405 & 1.569 & -1.460 & 1.566 & & \\
\hline Year $2002-2003 *$ Different & & & & & & & 0.313 & 1.970 \\
\hline \multirow[t]{2}{*}{ Year 2004-2005*Different } & & & & & & & -3.005 & 1.924 \\
\hline & \multicolumn{6}{|c|}{ Tobit (Dep.var.=parental leave) } & & \\
\hline Fathers & \multicolumn{6}{|c|}{$\mathrm{LL}=0$ days $/ 0 \mathrm{wks}, \mathrm{UL}=224$ days $/ 32 \mathrm{wks}$} & & \\
\hline Post*Different & 1.599 & 0.616 & 1.201 & 0.601 & 1.238 & 0.598 & & \\
\hline Year 2002-2003*Different & & & & & & & -0.343 & 0.738 \\
\hline Year 2004-2005*Different & & & & & & & 2.512 & 0.737 \\
\hline Mothers & \multicolumn{6}{|c|}{$\mathrm{LL}=70$ days $/ 10 \mathrm{wks}, \mathrm{UL}=224$ days $/ 32 \mathrm{wks}$} & & \\
\hline Post ${ }^{*}$ Different & -1.027 & 0.544 & -0.557 & 0.554 & -1.996 & 1.961 & & \\
\hline Year $2002-2003 *$ Different & & & & & & & -0.068 & 1.288 \\
\hline Year 2004-2005*Different & & & & & & & -1.987 & 1.260 \\
\hline \multicolumn{9}{|l|}{ Controls } \\
\hline Different, Year dummies & \multicolumn{2}{|c|}{ yes } & \multicolumn{2}{|c|}{ yes } & \multicolumn{2}{|c|}{ yes } & \multicolumn{2}{|c|}{ yes } \\
\hline Children, local and bigcity & \multicolumn{2}{|c|}{ no } & \multicolumn{2}{|c|}{ yes } & \multicolumn{2}{|c|}{ yes } & \multicolumn{2}{|c|}{ yes } \\
\hline Own and partner's age and log wages & \multicolumn{2}{|c|}{ no } & \multicolumn{2}{|c|}{ yes } & \multicolumn{2}{|c|}{ yes } & \multicolumn{2}{|c|}{ yes } \\
\hline Own and partner's level of education & \multicolumn{2}{|c|}{ no } & \multicolumn{2}{|c|}{ yes } & \multicolumn{2}{|c|}{ yes } & \multicolumn{2}{|c|}{ yes } \\
\hline Own and partner's occupation & \multicolumn{2}{|c|}{ no } & \multicolumn{2}{|c|}{ no } & & & & \\
\hline Number of observations & & & & & & & & \\
\hline
\end{tabular}

Note: Bold letters indicate significance at a 5\%-level, while italics indicate significance at a $10 \%$-level. 
Table A4. Estimation of the effect of economic incentives on father's and mother's leave taking. Fake reform

\begin{tabular}{|c|c|c|c|c|c|c|}
\hline \multirow[b]{3}{*}{ Explanatory variables } & \multicolumn{2}{|c|}{ (1) } & \multicolumn{2}{|c|}{ (2) } & \multicolumn{2}{|c|}{ (3) } \\
\hline & \multicolumn{2}{|c|}{ Benchmark } & \multicolumn{2}{|c|}{ Reform year 2000} & \multicolumn{2}{|c|}{ Reform year 2000} \\
\hline & Marg.eff. & Std.err. & Marg.eff & Std.err. & Marg.eff. & Std.err. \\
\hline & \multicolumn{6}{|c|}{ OLS $($ Dep.var.=total leave) } \\
\hline \multicolumn{7}{|l|}{ Fathers } \\
\hline Post fake reform $*$ Different & 2.022 & 0.989 & 0.662 & 1.224 & 1.187 & 1.493 \\
\hline \multicolumn{7}{|l|}{ Mothers } \\
\hline \multirow[t]{2}{*}{ Post fake reform $*$ Different } & -4.890 & 2.094 & -4.320 & 2.947 & -6.396 & 3.575 \\
\hline & \multicolumn{6}{|c|}{ Tobit (Dep.var.=parental leave) } \\
\hline Post fake reform*Different & 2.591 & 0.881 & -0.011 & 1.140 & $n$ & \\
\hline Mothers & \multicolumn{6}{|c|}{$\mathrm{LL}=70$ days $/ 10 \mathrm{wks}, \mathrm{UL}=224$ days $/ 32 \mathrm{wks}$} \\
\hline Post fake reform $*$ Different & -2.971 & 0.791 & -1.049 & 1.077 & n. & \\
\hline \multicolumn{7}{|l|}{ Controls } \\
\hline Different, Year dummies & \multicolumn{2}{|c|}{ yes } & \multicolumn{2}{|c|}{ yes } & \multicolumn{2}{|c|}{ no } \\
\hline Children, local and bigcity & \multicolumn{2}{|c|}{ yes } & \multicolumn{2}{|c|}{ yes } & \multicolumn{2}{|c|}{ yes } \\
\hline Own and partner's age and log wages & \multicolumn{2}{|c|}{ yes } & \multicolumn{2}{|c|}{ yes } & \multicolumn{2}{|c|}{ yes } \\
\hline Own and partner's level of education & \multicolumn{2}{|c|}{ yes } & \multicolumn{2}{|c|}{ yes } & \multicolumn{2}{|c|}{ no } \\
\hline Couple's type-level education cell $*$ year & \multirow{2}{*}{\multicolumn{2}{|c|}{ no }} & \multirow{2}{*}{\multicolumn{2}{|c|}{ no }} & \multirow{2}{*}{\multicolumn{2}{|c|}{ yes }} \\
\hline Sample & & & & & & \\
\hline Years included & \multicolumn{2}{|c|}{ All } & \multicolumn{2}{|c|}{$1997-2001$} & \multicolumn{2}{|c|}{$1997-2001$} \\
\hline Number of observations & \multicolumn{2}{|c|}{17680} & \multicolumn{2}{|c|}{8182} & 81 & \\
\hline
\end{tabular}

Note: Bold letters indicate significance at a 5\%-level, while italics indicate significance at a $10 \%$-level. N.a. indicates that the Tobit estimates are not available in this case as neither the fixed effects or dummy variable model are estimable. 